San Jose State University

SJSU ScholarWorks

Master's Theses

Master's Theses and Graduate Research

1989

\title{
Metabolism of the organophosphorous insecticide 0,0,0,0- tetrapropyl dithiopyrophosphate in the rat
}

Stephen Kramer Benedict

San Jose State University

Follow this and additional works at: https://scholarworks.sjsu.edu/etd_theses

\section{Recommended Citation}

Benedict, Stephen Kramer, "Metabolism of the organophosphorous insecticide 0,0,0,0-tetrapropyl dithiopyrophosphate in the rat" (1989). Master's Theses. 3053.

DOI: https://doi.org/10.31979/etd.jpet-dpy5

https://scholarworks.sjsu.edu/etd_theses/3053

This Thesis is brought to you for free and open access by the Master's Theses and Graduate Research at SJSU ScholarWorks. It has been accepted for inclusion in Master's Theses by an authorized administrator of SJSU ScholarWorks. For more information, please contact scholarworks@sjsu.edu. 


\section{INFORMATION TO USERS}

The most advanced technology has been used to photograph and reproduce this manuscript from the microfilm master. UMI films the text directly from the original or copy submitted. Thus, some thesis and dissertation copies are in typewriter face, while others may be from any type of computer printer.

The quality of this reproduction is dependent upon the quality of the copy submitted. Broken or indistinct print, colored or poor quality illustrations and photographs, print bleedthrough, substandard margins, and improper alignment can adversely affect reproduction.

In the unlikely event that the author did not send UMI a complete manuscript and there are missing pages, these will be noted. Also, if unauthorized copyright material had to be removed, a note will indicate the deletion.

Oversize materials (e.g., maps, drawings, charts) are reproduced by sectioning the original, beginning at the upper left-hand corner and continuing from left to right in equal sections with small overlaps. Each original is also photographed in one exposure and is included in reduced form at the back of the book. These are also available as one exposure on a standard $35 \mathrm{~mm}$ slide or as a $17^{\prime \prime} \times 23^{\prime \prime}$ black and white photographic print for an additional charge.

Photographs included in the original manuscript have been reproduced xerographically in this copy. Higher quality $6^{\prime \prime} \times 9^{\prime \prime}$ black and white photographic prints are available for any photographs or illustrations appearing in this copy for an additional charge. Contact UMI directly to order.

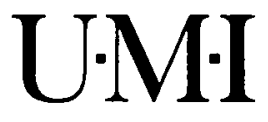

University Microfilms International

A Bell \& Howell Information Company 
Order Number 1337786

Metabolism of the organophosphorous insecticide 0,0,0,O-tetrapropyl dithiopyrophosphate in the rat

Benedict, Stephen Kramer, M.A.

San Jose State University, 1989

$\mathrm{U} \cdot \mathrm{M} \cdot \mathrm{I}$

300 N. Zeeb Rd.

Ann Arbor, MI 48106 
METABOLISM OF THE ORGANOPHOSPHOROUS INSECTICIDE $0,0,0,0$-TETRAPROPYL DITHIOPYROPHOSPHATE IN THE RAT

\author{
A Thesis \\ Presented to \\ The Faculty of the Department of Biological Sciences \\ San Jose State University \\ In Partial Fulfillment \\ of the Requirements of the Degree \\ Master of Arts
}

By

Stephen Kramer Benedict

May, 1989 
APPROVED FOR THE DEPARTMENT OF BIOLOGICAL SCIENCE

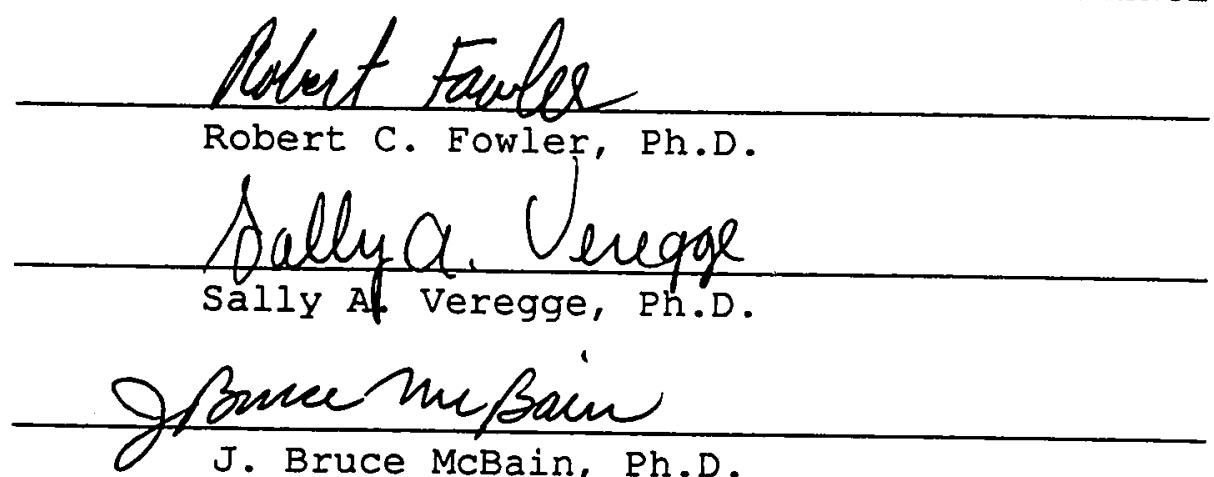

APPROVED FOR THE UNIVERSITY

Serex 91 fenfore

$i i$ 


\section{ABSTRACT}

1. The urinary and fecal excretions of radiocarbon in rats dosed via oral gavage (PO; per os) with [ $\left.{ }^{14} \mathrm{C}\right]-0,0,0,0-$ tetrapropyl dithiopyrophosphate (TDPP) at $630-1052 \mathrm{mg} / \mathrm{kg}$ were approximately $25 \%$ and $75 \%$ of the amount administered in 4 days, respectively. Approximately $80 \%$ of the radiocarbon was excreted within 48 hours.

2. Urinary metabolites were characterized by silica gel thin-layer chromatography (TLC) to be products of a much greater polarity than TDPP.

3. Nearly $100 \%$ of the fecal excretion was identified by TIC and gas chromatography/mass spectrometry as unchanged
TDPP.

4. In a rat dosed via intraperitoneal injection at approximately the same rate, urinary and fecal excretions of radiocarbon were $52 \%$ and $15 \%$ of the dose in 10 days, respectively. Urinary metabolites were characterized by TIC as the same in rats dosed $P O$, whereas fecal metabolites were shown by TLC to be dissimilar. 
TABLE OF CONTENTS

TITLE PAGE...........................

SIGNATURE PAGE.........................

ABSTRACT ................................

TABLE OF CONTENTS........................

ACKNOWLEDGMENTS . ........................

SUMMARY ..............................

INTRODUCTION $\ldots \ldots \ldots \ldots \ldots \ldots \ldots \ldots \ldots \ldots \ldots \ldots \ldots$

History ...........................

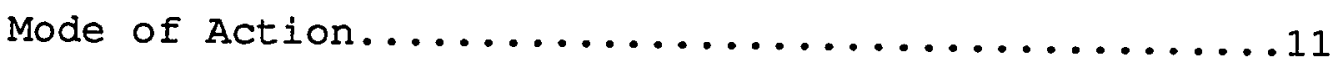

Biochemical Deactivation/Activation.............17

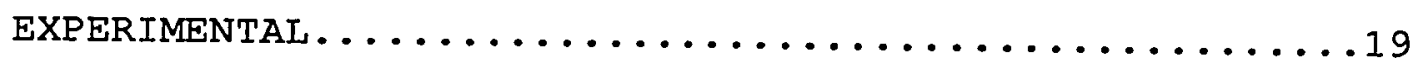

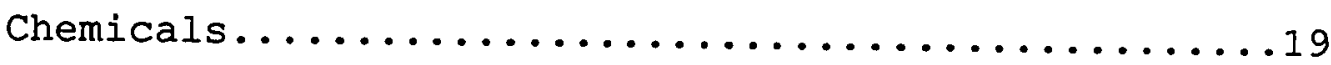

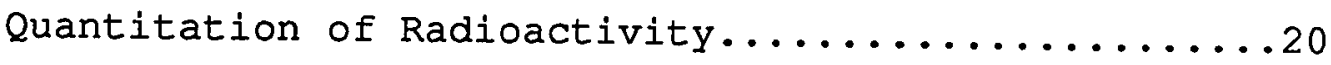

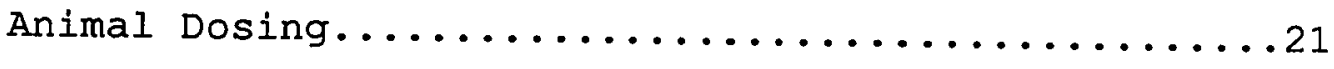

Metabolism Apparatus/Sample Collection............22

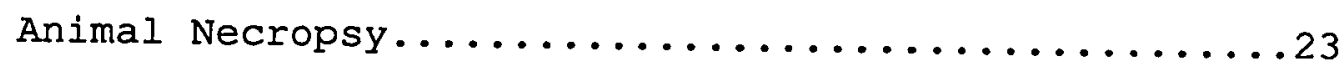

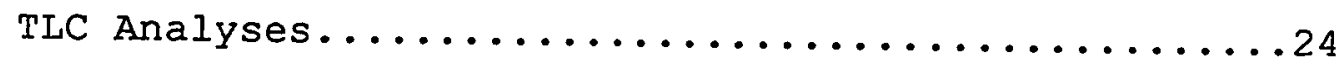

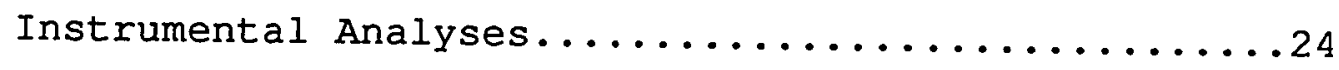

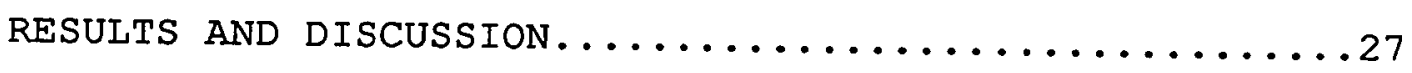

APPENDICES. .......................... 47

LITERATURE CITED .......................... 51 
ACKNOWLEDGMENTS

I would like to thank J. Bruce MCBain, Ph.D. of ICI Americas Inc., Mountain View, CA, for his technical guidance; professors Robert Fowler, Ph.D. and Sally Veregge, Ph.D. of San Jose State University for their editorial support and advice; Ben Giang Ph.D. of ICI Americas, Richmond, CA, for his mass spectral analyses and interpretations; and Judy Warrick of ICI Americas, Mountain View, CA, for her library assistance. Special thanks are due Cora Grubb for her structure drawings and word processing assistance. 
SUMMARY

Four Sprague-Dawley $C D$ rats (two male and two female) were dosed via oral gavage (PO; per os) with the organophosphate (OP) insecticide 0,0,0,0-tetrapropyl dithiopyrophosphate (TDPP) radiolabeled with carbon-14 in the propyl position. The dose rate given these rats ranged from $630 \mathrm{mg} / \mathrm{kg}$ to $1052 \mathrm{mg} / \mathrm{kg}$ (approximately $50 \%$ of the acute oral LD50 for TDPP in rats). Urine, feces and expired gases were collected from these rats at $12,24,48,72$, and 96 hours. At the time of sacrifice (96 hours) the remaining radiocarbon content was determined in tissues, organs and remaining carcasses by combustion analysis. The rate and route of excretion were determined. Radiocarbon excreted in the urine and feces was characterized by thin-layer chromatography (TLC). Fecal radiocarbon was purified and identified by gas chromatography/masis spectrometry (GC/MS) . TDPP was found to be retained only to a small degree as evidenced by the amount of material remaining $10.33 \%$ to $1.01 \%$ of the dose) in rat tissues at the time of sacrifice. Approximately $75 \%$ to $80 \%$ of the dose was excreted primarily as unchanged TDPP in the feces. The urine contained approximately 20-25\% of the dose radiocarbon as three unknown polar metabolites. 
Additionally one male Sprague-Dawley $C D$ rat was dosed with TDPP via intraperitoneal (IP) injection at approximately the same dose rate $(484 \mathrm{mg} / \mathrm{kg})$ as rats dosed Po. Urine and feces were collected at 12 and 24 hours followed by 24 hour interval collections through 240 hours. This rat was found to have vastly different excretion kinetics than rats dosed PO. Approximately 52\% of the dose was excreted slowly ( 5 s per day) in the urine and approximately $10 \%$ was excreted slowly ( 18 per day) in the feces. Tissue retention of TDPP was found to be much greater in this rat (28.4\% of the dose). Urinary metabolites were characterized by TLC to be the same as from rats dosed $P O$ whereas fecal metabolites were characterized by TLC to be unknown polar products.

This study has elucidated the non-absorptive nature of TDPP through the gastro intestinal tract when administered PO, yielding a possible explanation for the reported low mammalian toxicity (oral $L_{50}$ ) of TDPP in the rat. These findings are novel among OP insecticides in the rat. 
INTRODUCTION

\section{History}

Prior to the common usage of modern organic pesticides (organochlorines, organophosphates and carbamate esters), inorganic heavy metal based compounds were commonly used throughout the world for control of agricultural pests (Metcalf et al., 1951).

Beginning in the $1940^{\prime} \mathrm{s}$ widespread usage of organochlorine insecticides such as DDT became common. These compounds offered a great deal of control against insect pests and played an important role in agricultural output, forest protection and vector control for public health. They were found to be extremely effective but with continued use, many problems were determined to be associated with this class of insecticide. These problems were the manifestations of a high degree of lipid solubility, causing bio-retention, bio-magnification and resistance to bio-degradation (Carson, 1962). The culmination of these problems led to the general movement away from the use of organochlorine compounds in the United States. With the need for environmentally safer insecticides the use of $O P$ and carbamate ester insecticides in agricultural became much more common. 
TDPP is within the class of compounds collectively referred to as the OP insecticides. TDPP has a relatively low mammalian toxicity (acute oral $L_{50}$ is $1685 \mathrm{mg} / \mathrm{kg}$ in male rats, $475 \mathrm{mg} / \mathrm{kg}$ in female rats; Stauffer Chem. Co., 1985) as compared to other OP insecticides, yet is a highly effective agent for control of the chinch bug and sod webworm in lawn and turf. TDPP was first synthesized in 1959 by Schrader and in 1963 it was introduced as an insecticide by Stauffer Chemical Co. In 1987 TDPP was discontinued from commercial production due to economic considerations (Sine, 1987).

The first OP insecticide was tetraethyl pyrophosphate (TEPP). It was developed in Germany as a substitute for nicotine, which was in short supply in that country during World War II. TEPP, which has an oral $L D_{50}$ of 1.2-2.0 $\mathrm{mg} / \mathrm{kg}$, is highly toxic to mammals and is similar in structure yet much less toxic than TDPP (Casarett \& Doull, 1986). Many new OP compounds which give greater selective toxicity between insects and mammals have been developed since and are widely used today. Thus, study of these compounds is warranted in order to further understand their selective toxicity and biological fate within animals and the environment. Structures of TDPP and TEPP along with several common $O P$ insecticides and a comparison of their toxicities are given in Table 1. 

Table 1. Structure and Toxicity Comparison of TDPP with
other OP Insecticides. 1

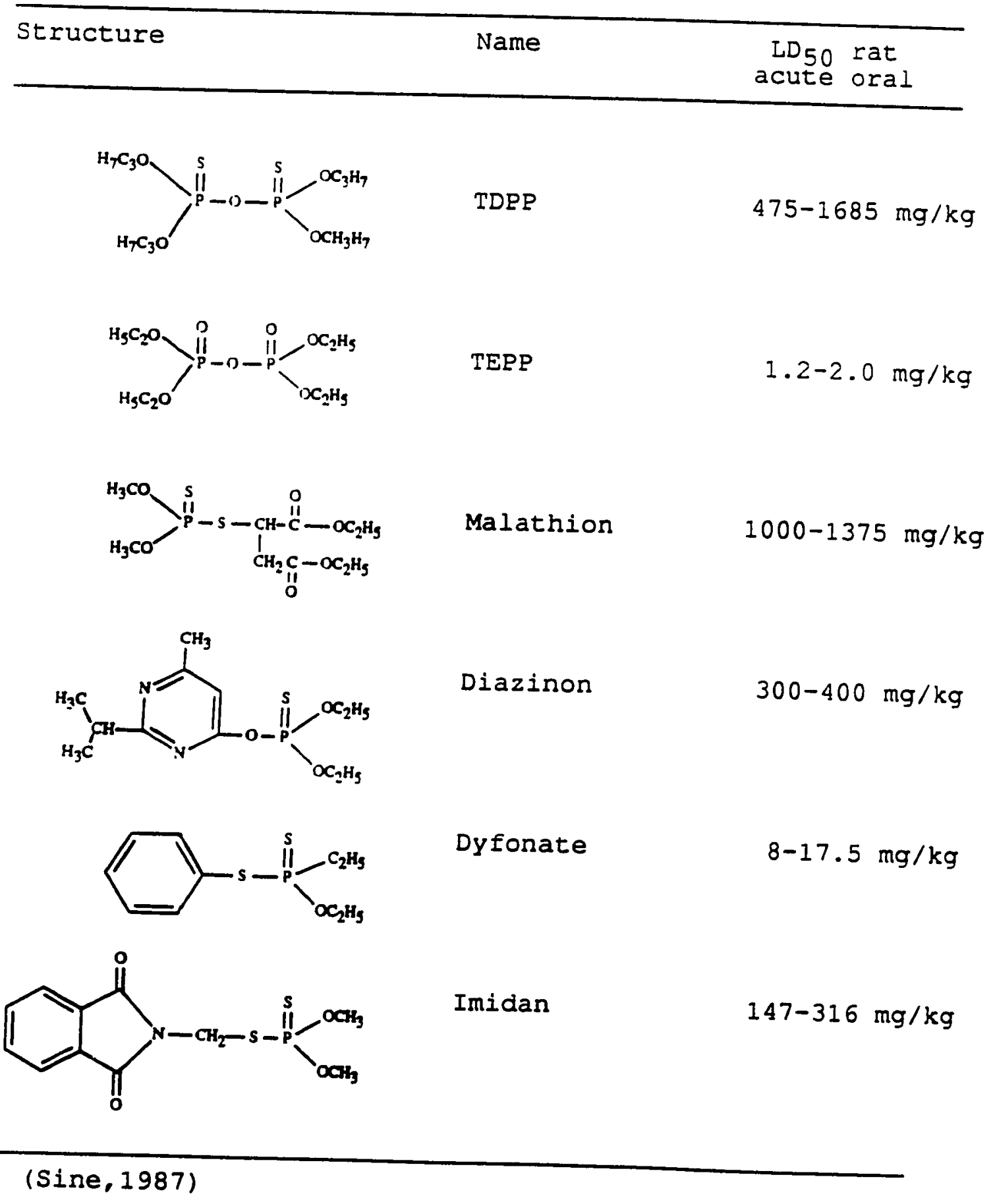


Mode of Action

Organophosphate insecticides exert their primary effect by inhibiting the enzyme acetylcholinesterase (AChE) at localized sites in the nervous system with subsequent accumulation of toxic levels of the neurohormone acetylcholine (ACh) (Gray, 1984).

AChE is synthesized in the nerve ending by the action of choline acetyltransferase (CAT) which catalyzes the acetylation of choline with acetyl coenzyme $A$ (CoA) (Rossier, 1977). In mammals $\mathrm{ACh}$ is stored in vesicles near the motor end-plate synapse awaiting release by stimulation of the action potential (AP). When an AP arrives at the motor-nerve terminal, there is an explosive release of $\mathrm{ACh}$ from 100 or more vesicles, following a latent period of approximately 0.75 millisecond (Kantz and Miledi, 1965). The intermediate steps appear to be as follows: depolarization of the terminal by the AP permits the influx of calcium ions, which hypothetically then bind to sites bearing negative charges on the internal surface of the axoplasmic membrane. This facilitates fusion of axonal and vesicular membranes, resulting in the extrusion of $\mathrm{ACh}$ into the synaptic cleft (Goodman and Gilman, 1985). This in turn causes the excitation of the postsynaptic membrane and propagation of the nerve impulse. The released $\mathrm{ACh}$ is then rapidly hydrolyzed by $\mathrm{AChE}$ into inactive acetic acid and 
choline before another impulse arrives (Holmstedt, 1971; see Figure 1). As long as $A C h$ remains in the region of the synaptic cleft, the original state of the postsynaptic membrane cannot be reestablished. Therefore, the inhibition of $\mathrm{AChE}$ results in the disturbance of nervous function which leads to severe and often lethal damage in the organism (Eto, 1974).

The usual cause of death in mammals is respiratory paralysis. Depending upon the type of cholinesterase inhibitor, this lethal symptom may be caused by a peripheral paralysis due to the blockage of neuromuscular transmission, by a disturbance of the function of the respiratory center in the medulla oblongata, or by a combination of both factors (Meeter et al., 1971).

The primary active sites of the AChE enzyme are the "anionic site" and the "esteratic site" (also referred to as the active center). The anionic site binds the cation portion of the substrate (either ACh or the OP xenobiotic) and the esteratic site, through a conformational change and hydrolysis binds the ester oxygen. This process is enhanced by the tetrahedral geometry of the phosphate moiety (Eto, 1974). OPs are referred to as true hemisubstrates for AChE due to the stable complex that is formed at the esteratic site (Massoulie and Bon, 1982). 

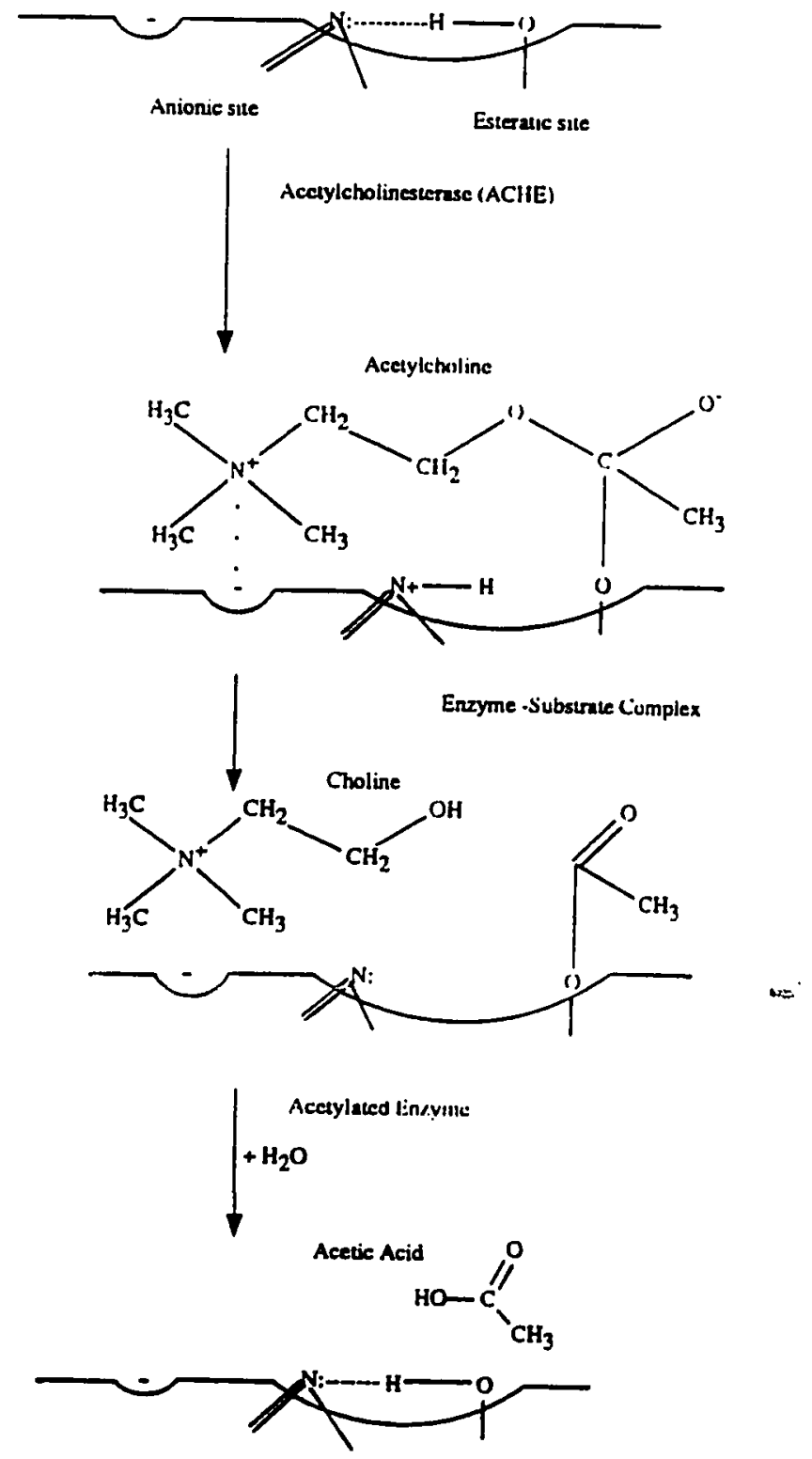

Regeneruted Enzyme

Eigure 1. Normal Function of AChE (modified from Casarett and Doull, 1986) 
Once bound to the OP, $\mathrm{AChE}$ is phosphorylated rather than acetylated, and thus inhibited from acting on ACh. This phosphorylated enzyme, which is a much more stable configuration than the acetylated enzyme, may be spontaneously reactivated through hydrolysis with water yielding the active $A C h E$ enzyme and dialkyl phosphoric acid (Eto, 1974).

The inhibited enzyme may also be reactivated through the removal of the OP molecule using pyridinealdoximes such as pralidoxime (2-PAM) which has been a standard method of therapy in accidental oP poisonings (Eto, 1974). The velocity of reactivation of phosphoylated AChE by pralidoxime varies with the nature of the phosphoryl group. Furthermore, phosphoylated AChE may undergo a fairly rapid process known as "aging" (see Figure 2), so that within minutes or hours it becomes completely resistant to reactivators such as pralidoxime (Ellin, 1982).

The "aging" process is caused by the hydrolytic loss of one alkyl group on the dialkyl phsphorylated AChE leading to a charged species. The primary effect of the "aging" process renders the AChE enzyme far more resistant to hydrolysis and unalterable by reactivating agents (Gray, 1984). Peripheral paralytic action and axonal degeneration produced by organophosphorus triesters are secondary 
examples of delayed neuropathies related to the "aging" process yet unrelated to AChE inhibition (Johnson, 1975). There are indications that other effects in mammals, notably delayed neurotoxicity caused by demyelination and delayed neurobehavioral effects, are caused by sublethal exposure to certain of the more lipophillic oP insecticides and are the result of actions unrelated to $\mathrm{AChE}$ inhibition (Gray, 1984). In one study deleterious genetic effects were demonstrated by the OP insecticides methyl parathion and malathion in the form of in vitro methylation of both single stranded and double stranded DNA (Wiaderkiewicz et al., 1986). The mass of evidence demonstrates, however, that the acute toxic effects of the OP insecticides in mammals is elicited by the elevated $A C h$ levels resulting from inhibition of the AChE enzyme.

OP insecticides, typically liposoluble, enter the insect via the cuticle, tracheal system, or digestive tract. Entry through the tracheal system may take the toxicant directly to the nerve or target organ, while entry by other routes involves the hemolymph as an intermediate carrier (Casida, 1973). 


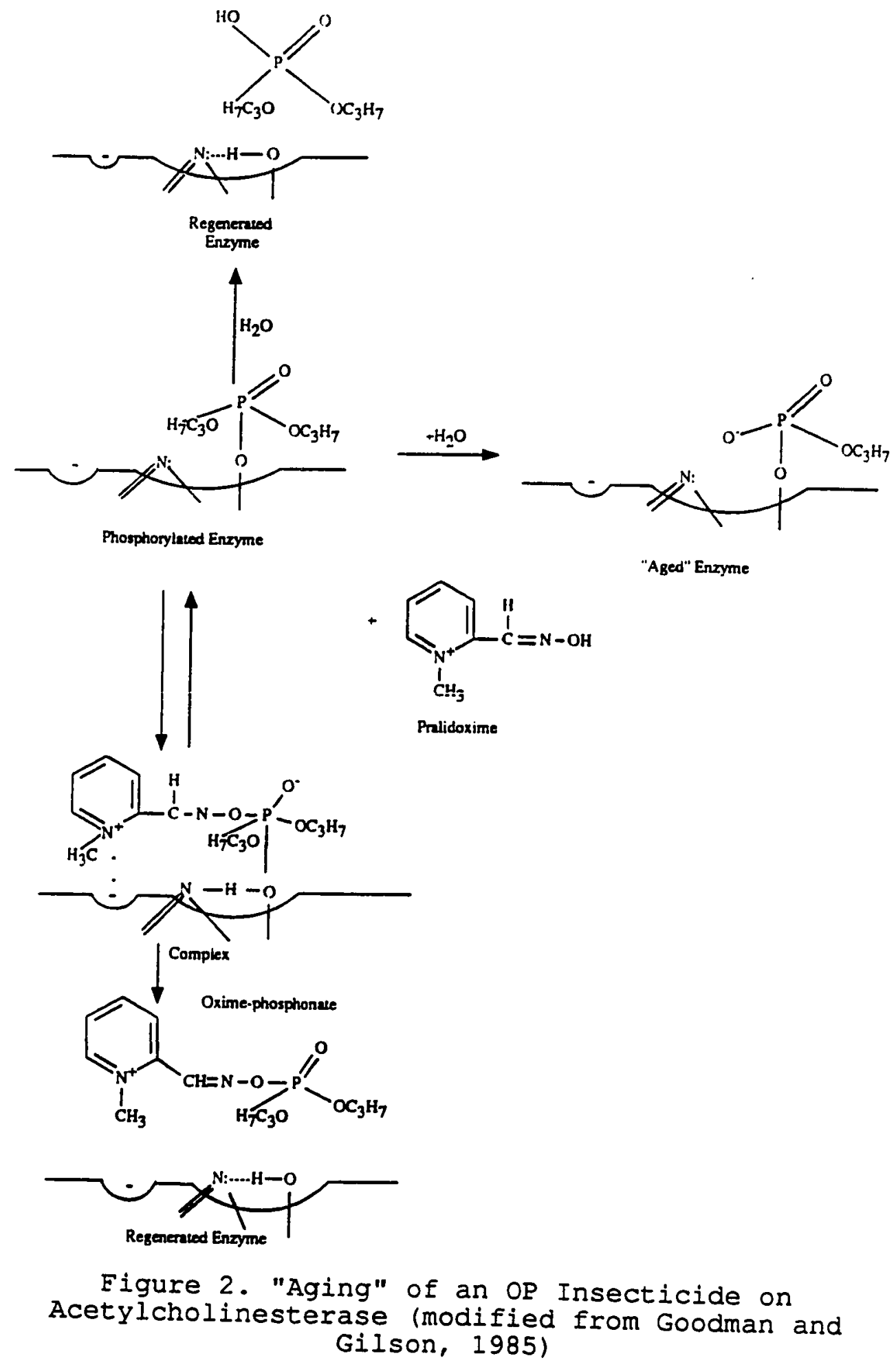


It is well established that AChE is inhibited and ACh concentration rises in OP treated insects (Kerkut and Gilbert, 1985). However, the precise chain of events between enzyme inhibition and death is still not established in insects. Obviously excess $A C h$ would have widespread harmful effects. Included in these may be an uncontrolled hormone release known to accompany op insect poisoning (Baillie and Wright, 1985). It has been suggested by Gerolt (1976) that a secondary factor in oP treated insect death may be accelerated integument water loss causing improper exchange of respiratory gases and degeneration of vital tissues.

\section{Biochemical Deactivation/Activation}

Generally, metabolism serves to detoxify OPs in both mammals and in insects. OP insecticides may undergo several different metabolic reactions leading to deactivation (Casarett and Doull, 1986). The two principal reactions which are of possible importance in TDPP metabolism are: o-dealkylation (such as removal of one or more of the propyl groups from TDPP) and anhydride bond cleavage (such as disruption of the P-O-P bond of TDPP).

In the process of activation the OP insecticide is metabolized in such a way that the toxicity of the primary metabolite becomes much greater than that of the parent 
compound (O'Brien, 1960). An important form of activation to be considered in the study of TDPP is oxidative desulfuration, where a thiophosphoryl group is transformed into a phosphoryl group which has a greater affinity for the AChE enzyme (Holmstedt, 1970).

Example:

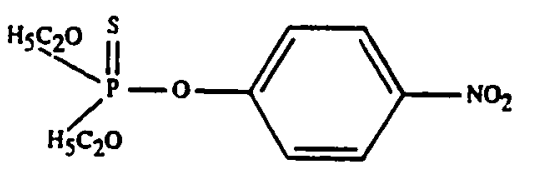

Parathion

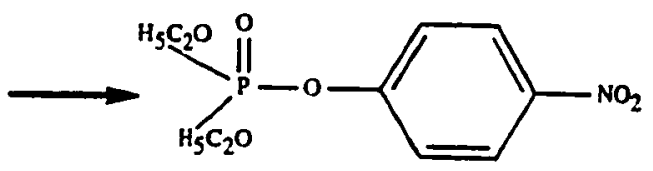

Paraoxon

Other forms of metabolism which are less likely to play a role in the fate of TDPP because of its structure, yet lead to activation in other insecticides include: sulfoxidation, N-dealkylation, alkyl hydroxylation and various nonoxidative rearrangements (Gray, 1984). These types of reactions are carried out both in cellular cytosol and by the mixed-function oxidase (MFO) system, which is associated with the endoplasmic reticulum (Casarett and Doull, 1986).

This study has elucidated the route and rate of excretion, characterized metabolites and where possible identified metabolites from rats dosed with TDPP both PO and via IP injection. 
EXPERIMENTAL

\section{Chemicals}

Radiolabeled ([ ${ }^{14} \mathrm{C}$-propyl]) and non-radiolabeled TDPP were provided by ICI Americas Inc., Western Research Center, Richmond CA. Toxicology, physical and chemical properties are given in Appendix I. The radiolabeled TDPP (compound code number WRC-7291-26-1) used in both PO and IP injection dosings had a specific activity of $14.16 \mathrm{mCi} / \mathrm{mmole}$. Radiopurity was determined by TLC to be 98.428 for [ $\left.{ }^{14} \mathrm{C}\right]$ TDPP used in PO dosings and $99.25 \%$ for $\left[{ }^{14} \mathrm{C}\right]$ TDPP used in IP dosing. Radiopurity analyses were made using solvent system A (see TLC section). The structure and label site of TDPP are given below:

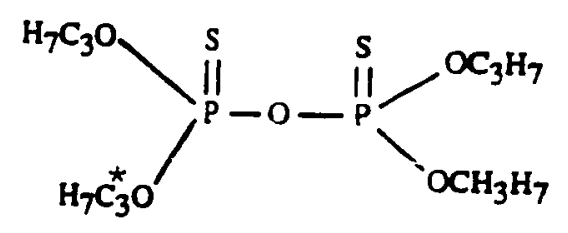

* denotes ${ }^{14} \mathrm{C}$ label site

Non-radiolabeled TDPP (compound code number WRC-474446) used in combination with radiolabeled TDPP for rats dosed $P O$ and as a reference standard for chromatographic analyses had a reported purity of 97.38. Non-radiolabeled TDPP (compound code number F43-R) used in combination with 
radiolabeled $T D P P$ for the rat dosed via IP injection had a reported purity of 92.18 .

\section{Quantitation of Radioactivity}

All urine and feces extract radioassays were performed directly by liquid scintillation counting (LSC) in $3 a 70 B$ LSC cocktail (Research Products International, Mount Prospect, IL) using a Tri-Carb ${ }^{\circledR}$ spectrophotometer model 4430 equipped with an external standard (Packard Instruments, Downers Grove, IL) . Counting efficiencies of samples were determined using the spectral index of the external standard (SIE). Feces samples from PO dosed rats were extracted by homogenization using a Kinematica Polytron ${ }^{\circledR}$ (Brinkmann Instruments, Westbury, NY) in ethyl acetate (two times) followed by methanol (one time). Solvent volumes of $10 \mathrm{~mL}$ to $30 \mathrm{~mL}$ (depending upon the fecal mass) were used to develop a slurry of each sample. Homogenized samples were centrifuged at $9,750 \times \mathrm{G}$ using a Sorvall ${ }^{\circledR}$ RC-2B centrifuge (Ivan Sorvall Co., Norwalk, CT) and decanted. Feces samples from the rat dosed via IP injection were extracted once with ethyl acetate by the same method. Organs and tissues removed from all rats were weighed fresh and homogenized using a Polytron in $2 \mathrm{~mL}$ to 6 $\mathrm{mL}$ of methanol. The carcasses (bone, muscle, hide and other remains) were ground by hand using a meat grinder and homogenized with a Polytron in $200 \mathrm{~mL}$ of methanol. 
Extracted feces, homogenized tissues and carcasses were weighed, aliquots removed, mixed with equal amounts of powdered cellulose, and combusted using a Tri-Carb Sample Oxidizer (Model 306, Packard Instruments); the released ${ }^{14} \mathrm{CO}_{2}$ was trapped in Carbo-Sorb II (Packard Instruments) and counted by LSC using Permafluor V ${ }^{\circledR}$ LSC cocktail (Packard Instruments). The sample oxidizer efficiency and LSC efficiency for this process were determined by combusting standard capsules containing glyceryl tripalmitate-1-14C (Oxi-Test ${ }^{\circledR}$, E\&K Scientific Products, Saratoga, CA). Aliquots of sodium hydroxide from traps within the metabolism apparatus used to trap ${ }^{14} \mathrm{CO}_{2}$ from $P O$ dosed rats were counted in a gel of 3a70B cocktail/water $(3: 1)$. The distribution of radioactive material adsorbed on silica gel TLC plates was quantified either by computer analysis using the Ambis ${ }^{\circledR}$, Mark II, automated radioanalytic imaging system (Automated Microbiology systems, San Diego, CA) utilizing an argon/methane mixture (99:1) as the ionizable gas or by ISC of scraped silica gel from the plate surface, after adding $1 \mathrm{~mL}$ methanol and $10 \mathrm{~mL} 3 \mathrm{a} 70 \mathrm{~B}$ cocktail to each scraping.

\section{Animal Dosing}

Adult male and female Sprague-Dawley CD rats (210$300 \mathrm{~g}$ ) were obtained from Charles River Laboratories (Wilmington, DE) and held in plastic cages according to sex 
with access to Purina Laboratory Rodent Chow \#5002 and water ad libitum. Prior to treatment, the rats to be dosed were acclimatized for 24 hours in metabolism cages (described below). Water and food were withheld during this period. Dosing solution was prepared to deliver approximately $50 \%$ of the acute oral $L D_{50}$ (see Appendix II for dosing solution calculations). Two male and two female rats were weighed, then dosed by oral gavage and returned to their respective metabolism cages. Water was provided immediately and at eight hours post dose food was also provided for the remainder of the in-life phase of the study.

Additionally, one Sprague-Dawley CD male rat was dosed by IP injection. This rat was handled in the same manner as those described above. See Appendix III for dosing solution calculations.

\section{Metabolism Apparatus/Sample collection}

Custom made, all glass metabolism cages (Stanford Glassblowing, Palo Alto, $C A$ ) designed to collect urine, feces and expired gases in separate traps were used for all rats. Expired gases from each of the four cages were drawn by vacuum through a scrubbing tower containing $1.0 \mathrm{~N}$ sodium hydroxide used to trap ${ }^{14} \mathrm{CO}_{2}$ lexpired gasses were not trapped from the rat dosed via IP injection). Urine and feces traps were refrigerated using circulating coolant to 
inhibit microbial growth. Urine and feces were collected at 12, 24, 48, 72 and 96 hours from rats dosed $P O$ and at 12 and 24 hours followed by daily collections through 240 hours from the rat dosed via IP injection.

At each collection interval, urine was radioassayed and frozen for future chromatographic analyses. Feces were frozen for future extraction, combustion and chromatographic analyses. At the conclusion of the in-life phase of the study, the sodium hydroxide trap contents were removed from cages of $\mathrm{PO}$ dosed rats and radioassayed. All cages were rinsed with methanol/water $(1: 1)$ which was radioassayed by ISC.

\section{Animal Necropsy}

At 96 hours post dose each of the four rats dosed PO was sacrificed by exsanguination following cervical dislocation under ether anesthesia. The rat dosed via IP injection was sacrificed by the same method after 240 hours. Gross observation of organ systems were made. Blood, lungs, liver, kidney and G.I. tract were removed from each rat. These tissues and the remaining carcasses were weighed fresh and subjected to combustion analysis for ${ }^{14} \mathrm{C}$ content. 
TLC Analyses

Analyses were run using Merck silica gel 60 F $_{254}$ plates, $0.25 \mathrm{~mm}$ thickness (E.M. Merck Reagents, American Scientific Products, McGraw Park, IL), developed with various solvent systems as mobile phases. TLC solvent systems and a comparison of TDPP $R_{f}$ values are given in Table 2 .

Detection of radioactivity on the TLC plates was achieved by autoradiography using $x$-ray film (Kodak SB-5) or by using an Ambis automated radio-analytical imaging system. Non-radiolabeled TDPP reference standard was detected using a $0.5 \%(w / v)$ solution of 2,6 -dibromo-N-chloro-p-benzoquinone imine in cyclohexane as a fine spray applied to the surface of TLC plates followed by exposure to concentrated $\mathrm{HCl}$ vapor. Upon detection, non-radiolabeled reference standard appeared as an orange spot on a yellow background.

\section{Instrumental Analyses}

Chemical ionization MS utilizing methane as the ionizing gas was used to identify products isolated and purified from feces extracts of po dosed rats. Analyses were performed by Ben Giang of ICI Americas, Richmond, CA, utilizing the following instruments and conditions: Hewlett Packard model 5790 GC, DB-1 fused silica capillary column, $10 \mathrm{~m} \times 0.25 \mathrm{~mm}$ i.d., $0.25 \mu \mathrm{m}$ film thickness; injection port 
Table 2. TLC Behavior of TDPP on Merck Silica Gel Plates (60 $\mathrm{F}_{254} 0.25 \mathrm{~mm}$ Thickness).

\begin{tabular}{lr} 
Solvent system & $R_{f}$ \\
\hline A) hexane/ diethyl ether (1:1) & 0.94 \\
B) pentane/chloroform (3:1) & 0.48 \\
C) cyclohexane/chloroform (1:1) & 0.55 \\
D) cyclohexane/diethyl ether (99:1) & 0.28 \\
E) toluene (100\%) & 0.75 \\
F) ethyl acetate/88\% formic acid (20:1) & 0.93 \\
G) n-butanol/acetic acid (conc.)/water (4:1:1) & 0.90
\end{tabular}


temperature of $220^{\circ} \mathrm{C}$, column oven temperature program from $50^{\circ} \mathrm{C}$ to $320^{\circ} \mathrm{C}$ at $20^{\circ} \mathrm{C} / \mathrm{min}$, head pressure $10 \mathrm{p} . \mathrm{s} . \mathrm{i}$, splitless mode of injection, $1 \mu \mathrm{L}$ injection volume; VG model 7070-hf double focusing high resolution MS, mass range 40-550 amu at $1 \mathrm{sec} / \mathrm{scan}, 200 \mu$ amp trap current. This method was selected based upon the volatility, thermal stability and ionizability of TDPP. 


\section{RESULTS AND DISCUSSION}

Percent distributions of radiocarbon recovery from urine and feces for rats dosed Po are given in Table 3 and depicted graphically in Figures 3 and 4 . Excretion kinetics and biological half-lives are given in Table 4 and depicted graphically in Figures 5 and 6 . Computer analyses used to generate linear regression plots of least squares function fitted lines to the data points were performed on $\mathrm{RS} / 1^{\circ}$ computer software (BBN Software Products corp., Cambridge, MA). The lines which best fit the data followed first order excretion kinetics.

Percent distribution of radiocarbon recovery from urine and feces for the rat dosed via IP injection is given in Table 5 and depicted graphically in Figure 7. Excretion kinetics and biological half-life are given in Table 6 and depicted graphically in Figure 8 .

TDPP was found to be retained in the tissues of rats dosed PO only to a small degree as evidenced by the amount of radiocarbon remaining ( $0.3 \%$ to 1.08 of the dose) at the time of sacrifice. These findings are in sharp contrast to the large amount (28.48 of the dose) of radiocarbon retained in the rat dosed via IP injection. 
Table 3. Cumulative Percent Recovery of ${ }^{14} \mathrm{C}$ from Rats Dosed PO. 1

\begin{tabular}{rrrrrrrrr}
\hline & Hours & Urine & Feces & ${ }^{14} \mathrm{CO}_{2}$ & Tissues & Cage & Total \\
\hline Male 1) & 12 & 7.1 & 0.4 & - & - & - & 7.5 \\
& 24 & 16.9 & 1.2 & - & - & - & 18.1 \\
& 48 & 21.5 & 74.4 & - & - & - & 95.9 \\
& 72 & 22.2 & 75.2 & - & - & - & 97.4 \\
Male 21 & 96 & 22.4 & 75.9 & 0.1 & 0.7 & 0.2 & 99.3 \\
& 12 & 4.0 & 0.1 & - & - & - & 4.1 \\
& 24 & 14.1 & 14.1 & - & - & - & 28.2 \\
& 48 & 22.2 & 83.9 & - & - & - & 106.0 \\
& 72 & 24.7 & 85.2 & - & - & - & 109.9 \\
Female 1) & 96 & 25.4 & 85.3 & 0.0 & 1.0 & 0.8 & 112.6 \\
& 12 & 10.1 & 0.0 & - & - & - & 10.1 \\
& 24 & 13.9 & 31.1 & - & - & - & 45.0 \\
& 48 & 20.3 & 74.2 & - & - & - & 94.5 \\
& 72 & 21.0 & 77.4 & - & - & - & 98.4 \\
& 96 & 21.4 & 77.6 & 0.1 & 0.4 & 1.3 & 100.8 \\
Female 21 & 12 & 7.9 & 12.5 & - & - & - & 20.4 \\
& 24 & 11.0 & 22.8 & - & - & - & 33.8 \\
& 48 & 14.8 & 76.3 & - & - & - & 91.1 \\
& 72 & 19.6 & 78.0 & - & - & - & 97.6 \\
& 96 & 19.9 & 79.2 & 0.1 & 0.3 & 1.6 & 101.1 \\
\hline
\end{tabular}

1 Values for ${ }^{14} \mathrm{CO}_{2}$, tissues and cage rinses reflect sample collection following rat sacrifice. 
Male 1

$a$
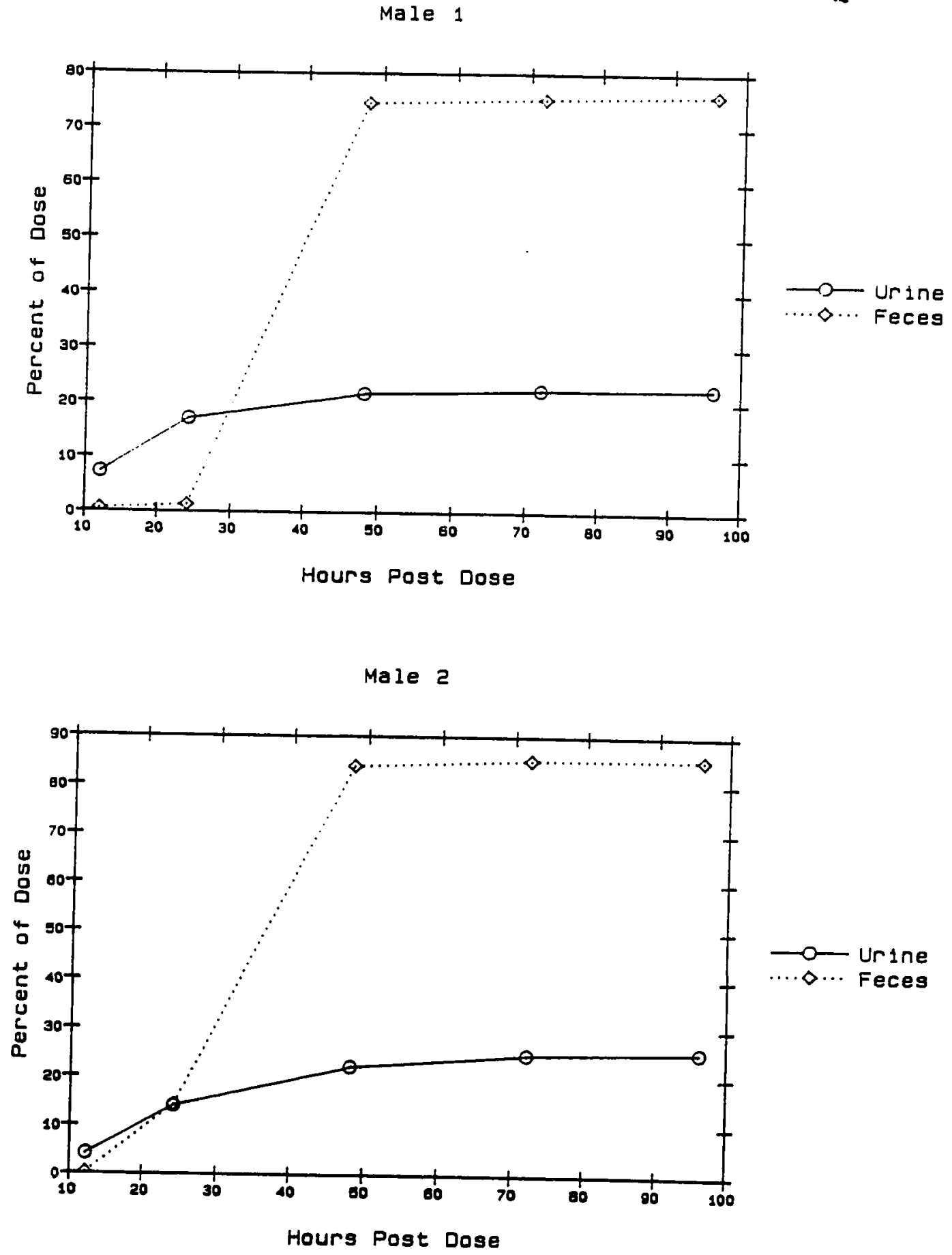

Eigure 3. Percent ${ }^{14} \mathrm{C}$ Excretion Recovery from Male Rats 
Female 1

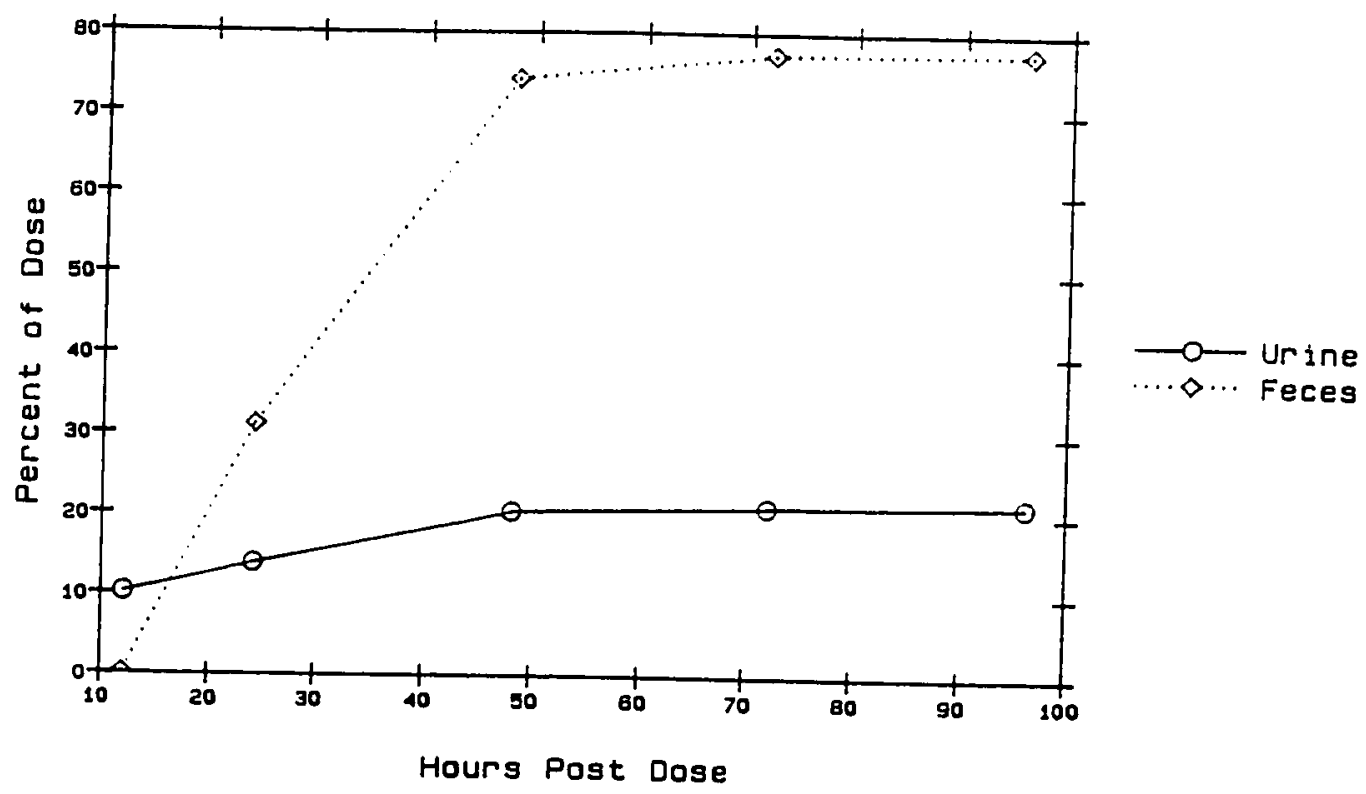

Female 2

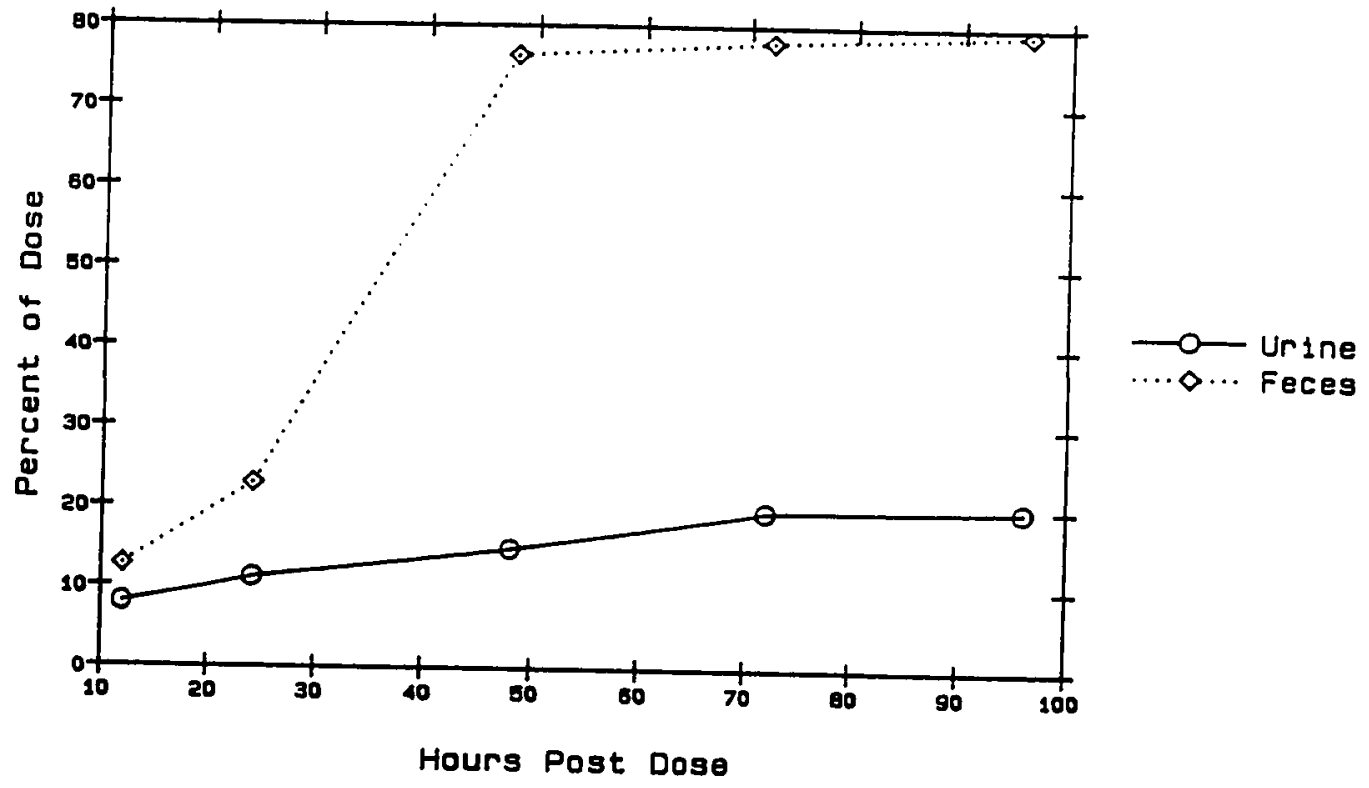

Eigure 4. Percent ${ }^{14} \mathrm{C}$ Excretion Recovery from Female Rats 
Table 4. Biological Half-life of TDPP in Rats Dosed PO.1 Common Log of the Fraction Remaining in Rats 2

\begin{tabular}{lrccc}
\hline $\begin{array}{l}\text { Hours } \\
\text { Post Dose }\end{array}$ & $\begin{array}{c}\log F \\
\text { male 1 }\end{array}$ & $\begin{array}{c}\log F \\
\text { male } 2\end{array}$ & $\begin{array}{c}\log F \\
\text { female } 1\end{array}$ & $\begin{array}{c}\log F \\
\text { female } 2\end{array}$ \\
\hline 12 & -0.0342 & -0.0163 & -0.0463 & -0.0978 \\
24 & -0.0869 & -0.1250 & -0.2571 & -0.1771 \\
48 & -1.4579 & -1.2347 & -1.2033 & -1.0035 \\
72 & -1.7322 & -1.6170 & -1.6249 & -1.5702 \\
\hline
\end{tabular}

Biological Half-lives

\begin{tabular}{llc}
\hline Rat & $K$ & $t_{1 / 2}$ (hours) \\
\hline Male 1 & -0.0320 & 21.63 \\
Male 2 & -0.0292 & 23.69 \\
Female 1 & -0.0279 & 24.80 \\
Female 2 & -0.0262 & 26.50 \\
\hline
\end{tabular}

Half life $\left(t_{1 / 2}\right)$ : time required for elimination of $50 \%$ of the dose administered

$\mathrm{kt}=2.303 \log \mathrm{F}^{\circ} / \mathrm{F}$

$k t=2.303 \log 2$

$t_{1 / 2}=0.693 / \mathrm{K}$

where: $F^{\circ}=$ fraction of dose administered $(1 / 1)$

$F=$ fraction of the dose at half Iife $\left(F^{\circ} / 2\right)$

$\mathrm{K}=$ first order rate constant (from slopes in Figures 5 and 6)

$t=$ time (hours)

2 Data normalized from percent recoveries. 


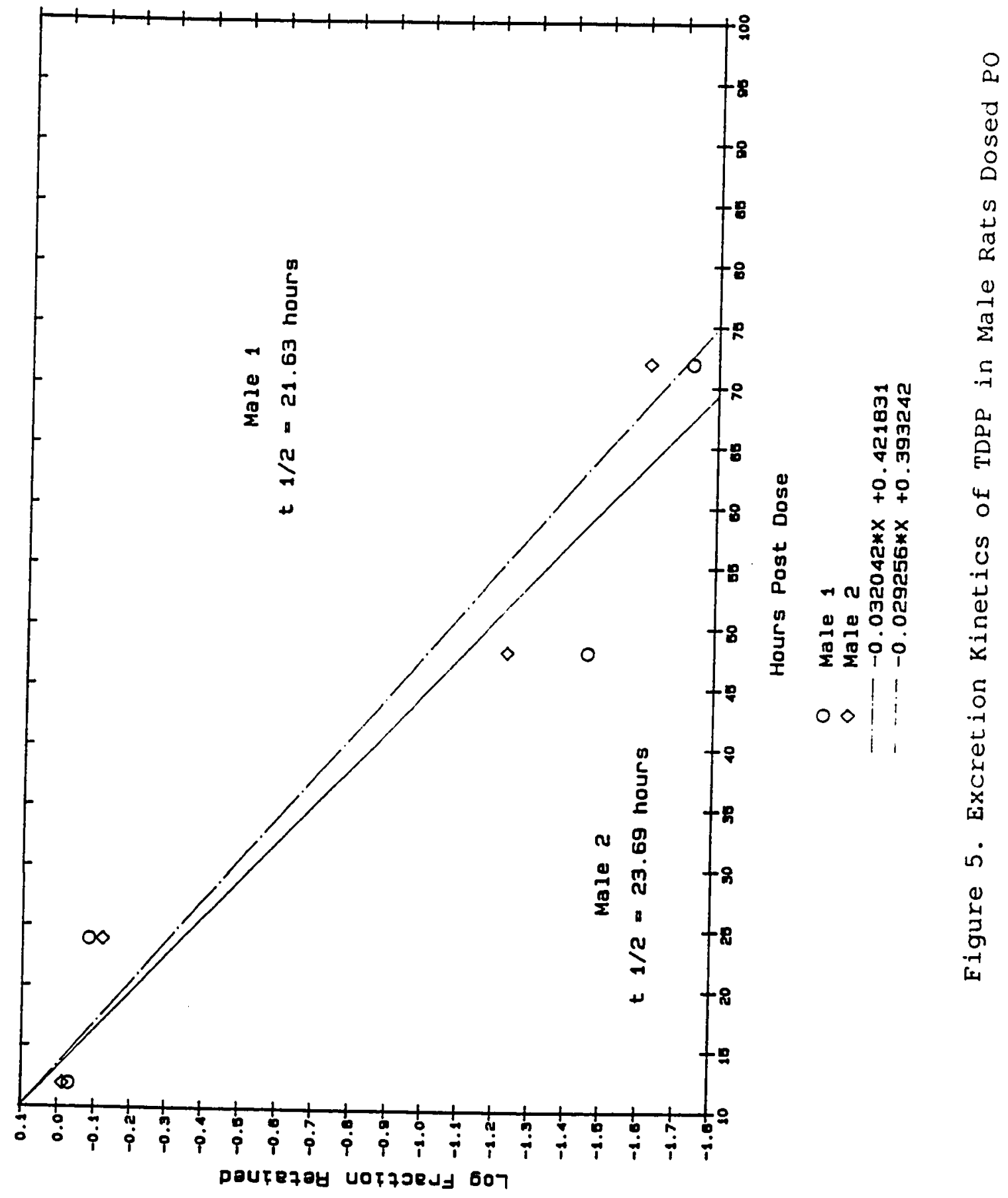




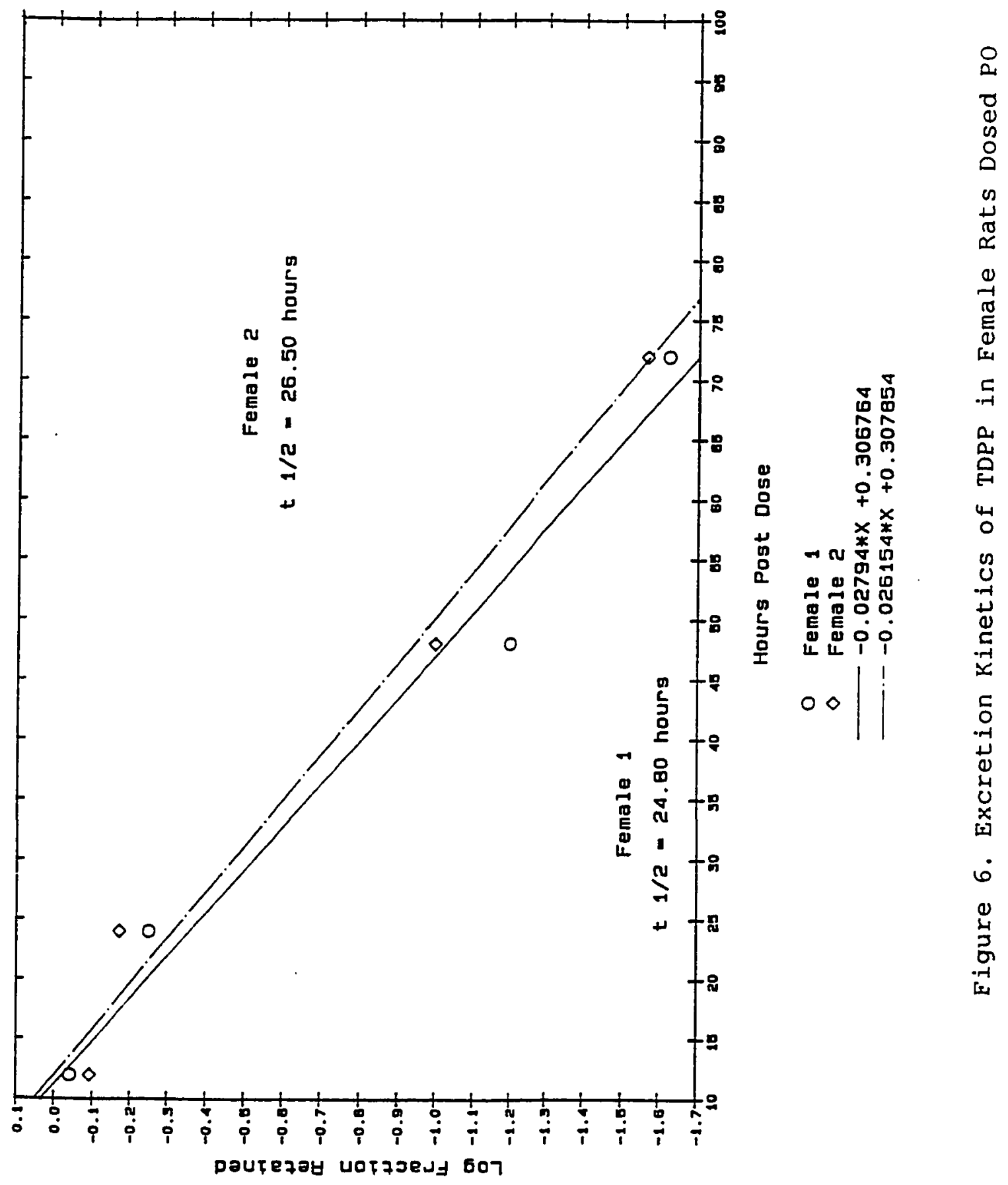


Table 5. Cumulative Percent Recovery of ${ }^{14} \mathrm{C}$ from Rat Dosed via IP Injection. 1

\begin{tabular}{crrrrr}
\hline Hours & Urine & Feces & Tissues & Cage & Total \\
\hline 12 & 2.29 & 0.16 & - & - & 2.45 \\
48 & 13.57 & 2.25 & - & - & 15.82 \\
72 & 19.81 & 3.66 & - & - & 23.47 \\
96 & 23.85 & 4.66 & - & - & 28.51 \\
120 & 29.66 & 5.73 & - & - & 35.39 \\
144 & 35.39 & 5.91 & - & - & 42.30 \\
168 & 41.29 & 7.68 & - & - & 48.97 \\
192 & 46.94 & 9.27 & - & - & 56.21 \\
216 & 50.61 & 10.07 & - & - & 60.68 \\
240 & 52.40 & 10.58 & 28.36 & 2.26 & 93.60 \\
\hline
\end{tabular}

1 Values for tissues and cage rinse recoveries reflect sample collection following rat sacrifice. 


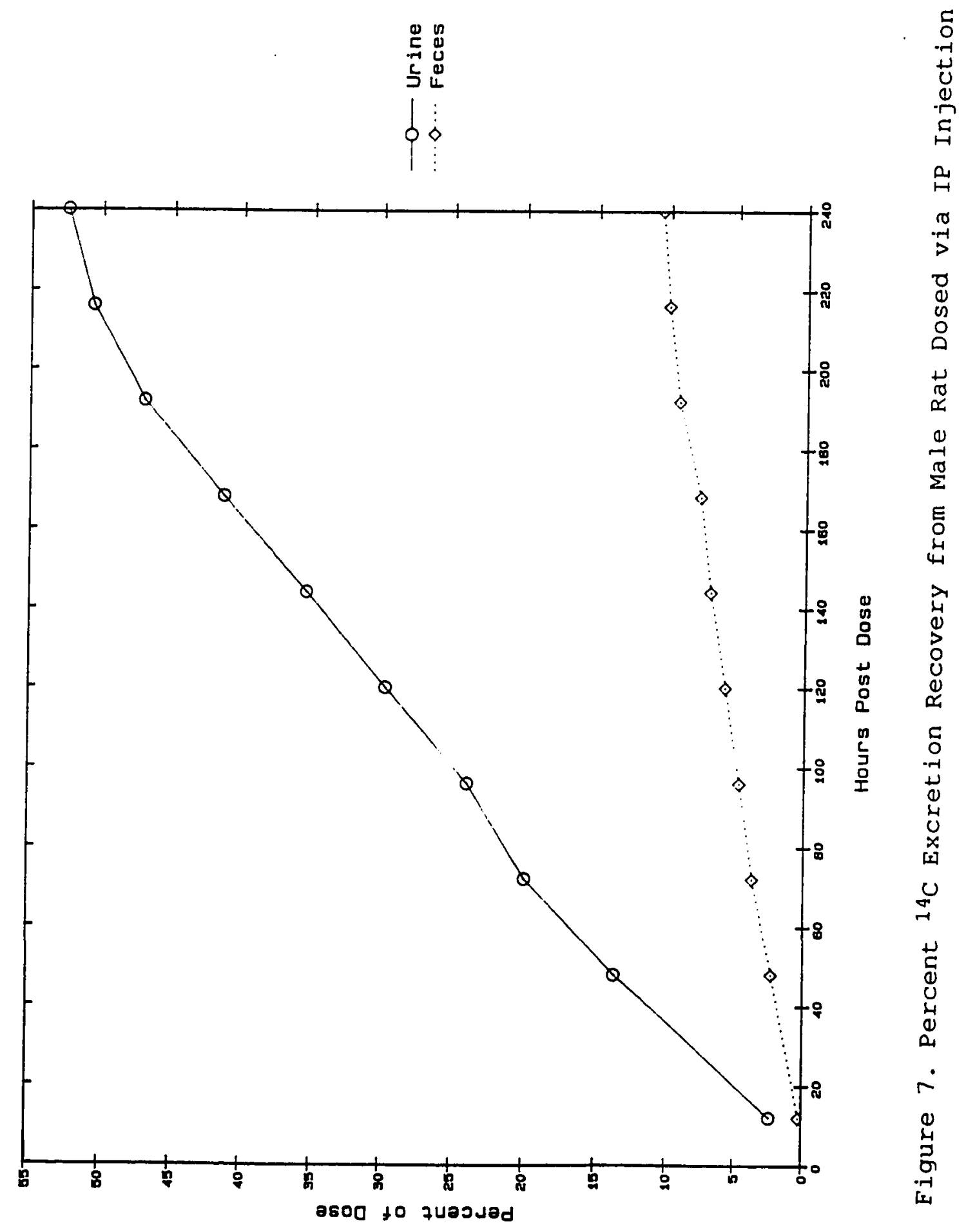


Table 6. Biological Half-life of TDPP in Rat Dosed via IP Injection. 1

Common Log of the Fraction Remaining the Rat $^{2}$

\begin{tabular}{ll}
\hline $\begin{array}{l}\text { Hours } \\
\text { Post Dose }\end{array}$ & Log $F$ \\
\hline 12 & -0.0804 \\
48 & -0.1254 \\
72 & -0.1578 \\
96 & -0.2060 \\
120 & -0.2612 \\
144 & -0.3216 \\
168 & -0.3985 \\
192 & -0.3985 \\
216 & -0.4538 \\
\hline
\end{tabular}

Biological Half-life

\begin{tabular}{lcc}
\hline Rat & $K$ & $t_{1 / 2}$ (hours) \\
\hline Male & -0.02158 & 321.19 \\
\hline
\end{tabular}

1

$$
\begin{aligned}
& \text { Half life }\left(t_{1 / 2}\right): \begin{array}{c}
\text { time required for elimination of } 50 \% \\
\text { of the dose administered }
\end{array} \\
& k t=2.303 \log \mathrm{F}^{\circ} / \mathrm{F} \\
& \mathrm{kt}=2.303 \mathrm{log} 2 \\
& \mathrm{t}_{1 / 2}=0.693 / \mathrm{K} \\
& \text { where: } \mathrm{F}^{\circ}=\text { fraction of dose administered (1/1) } \\
& \mathrm{F}=\text { fraction at the half life }\left(\mathrm{F}^{\circ} / 2\right) \\
& \mathrm{K}=\text { first order rate constant (from slopes } \\
& t=\text { in Figure } 8)
\end{aligned}
$$

2 Data normalized from percent recoveries. 


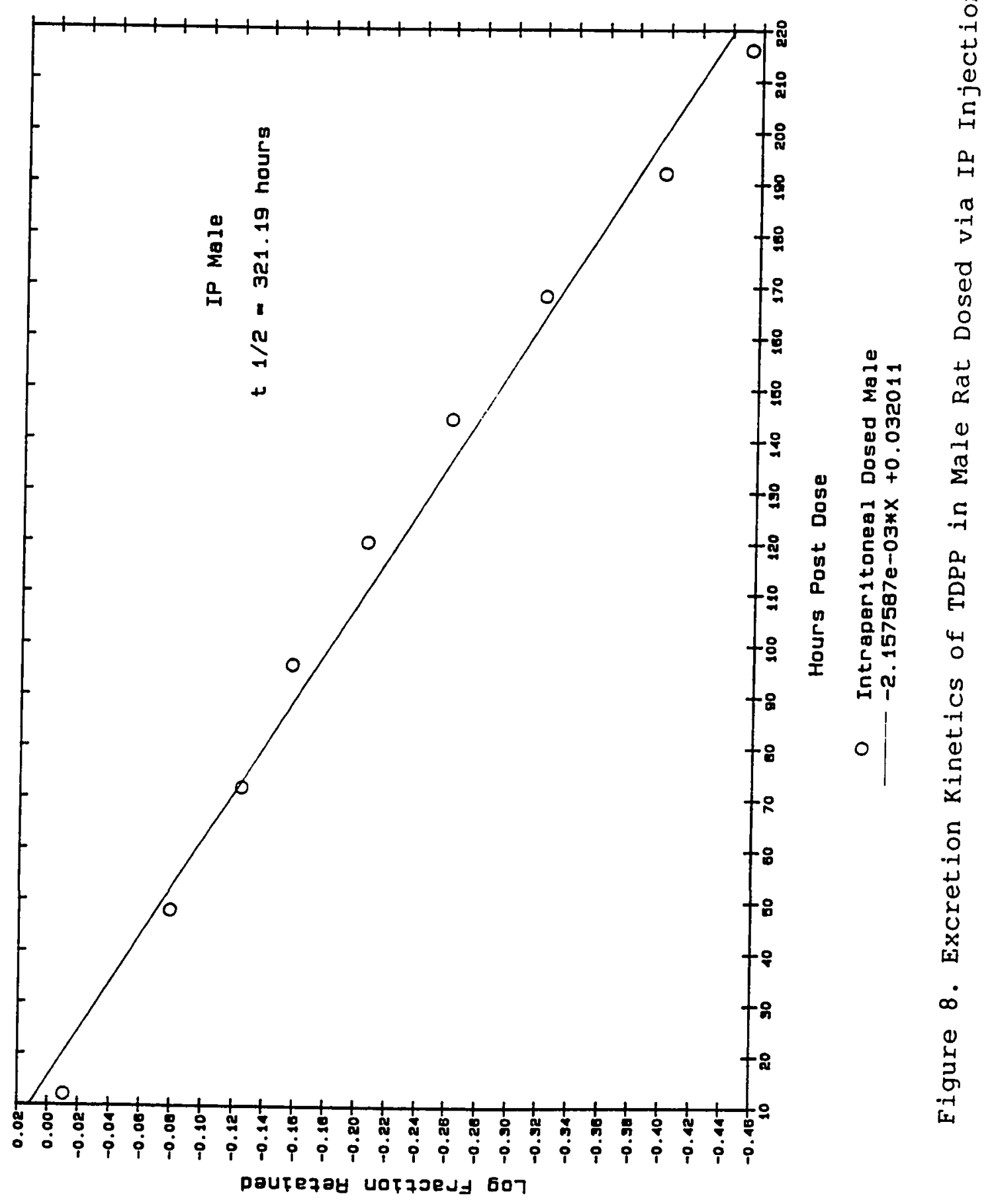


Tissue concentrations were calculated in terms of ppm TDPP equivalents and are given in Tables 7 and 8 for rats dosed PO and by IP injection, respectively.

Elimination of radiocarbon as ${ }^{14} \mathrm{CO}_{2}$ from rats dosed $\mathrm{PO}$ was shown to be a very minor pathway, ranging from $0.09 \%$ to $0.11 \%$ of the administered dose.

Whole urine and ethyl acetate feces extracts from each sampling interval were analyzed by TLC with TDPP reference standard. Autoradiograms of TLC separations from rats dosed $\mathrm{PO}$ are shown in Figure 9 (urine) and Figure 10 (feces).

Urine from rats dosed $P O$ was found to contain three polar unknown metabolites present in the amounts of approximately 56\%, $29 \%$ and $8 \%$, of the 20\%-25\% radiocarbon dose excreted through the urine. These metabolites were not volatile enough to be identified by GC/MS, and an attempt at derivatization using t-butyl dimethylchlorosilane/imidazole in order to improve their volatility was unsuccessful. Urinary metabolites from the rat dosed via IP injection are suspected to be the same as those found in rats dosed PO, as determined by relative $R_{f}$ values using the same TLC system. 

Table 7. TDPP Tissue Residues from Rats Dosed $P O$
Expressed in Terms of TDPP ppm Equivalents.

\begin{tabular}{ccccc}
\hline Tissue & Male 1 & Male 2 & Female 1 & Female 2 \\
\hline Blood & 3.32 & 2.91 & 2.20 & 1.50 \\
Kidney & 9.33 & 11.83 & 16.58 & 19.78 \\
Liver & 19.58 & 27.13 & 25.51 & 20.68 \\
G.I. Tract & 1.64 & 4.86 & 4.45 & 3.90 \\
Lungs & 1.29 & 1.50 & 0.27 & 1.06 \\
Carcass & 3.76 & 8.69 & 2.34 & 2.61 \\
\hline
\end{tabular}

1 Where $\mathrm{ppm}=$ Total dpm of whole sample/g fresh weight of whole sample Specific activity of TDPP dose $(\mathrm{dpm} / \mu \mathrm{g})$

$=\mu \mathrm{g} \mathrm{TDPP} / \mathrm{g}$ tissue

Specific activity of TDPP dosing solution $=354.4 \mathrm{dpm} / \mu \mathrm{g}$ 
Table 8. TDPP Tissue Residues from Rat Dosed via IP Injection. Expressed in Terms of TDPP ppm Equivalents. 1

\begin{tabular}{cc}
\hline Tissue & ppm equivalents \\
\hline Blood & 4.65 \\
Kidney & 14.16 \\
Liver & 21.13 \\
G.I. Tract & 21.45 \\
Lungs & 4.26 \\
Carcass & 144.03 \\
\hline
\end{tabular}

1 Where $\mathrm{ppm}=$ Total dpm of whole sample/g fresh weight of whole sample Specific activity of TDPP dose (dpm/ $\mu \mathrm{g})$

$=\mu g \operatorname{TDPP} / g$ tissue

Specific activity of TDPP dosing solution $=647.7 \mathrm{dpm} / \mu \mathrm{g}$ 


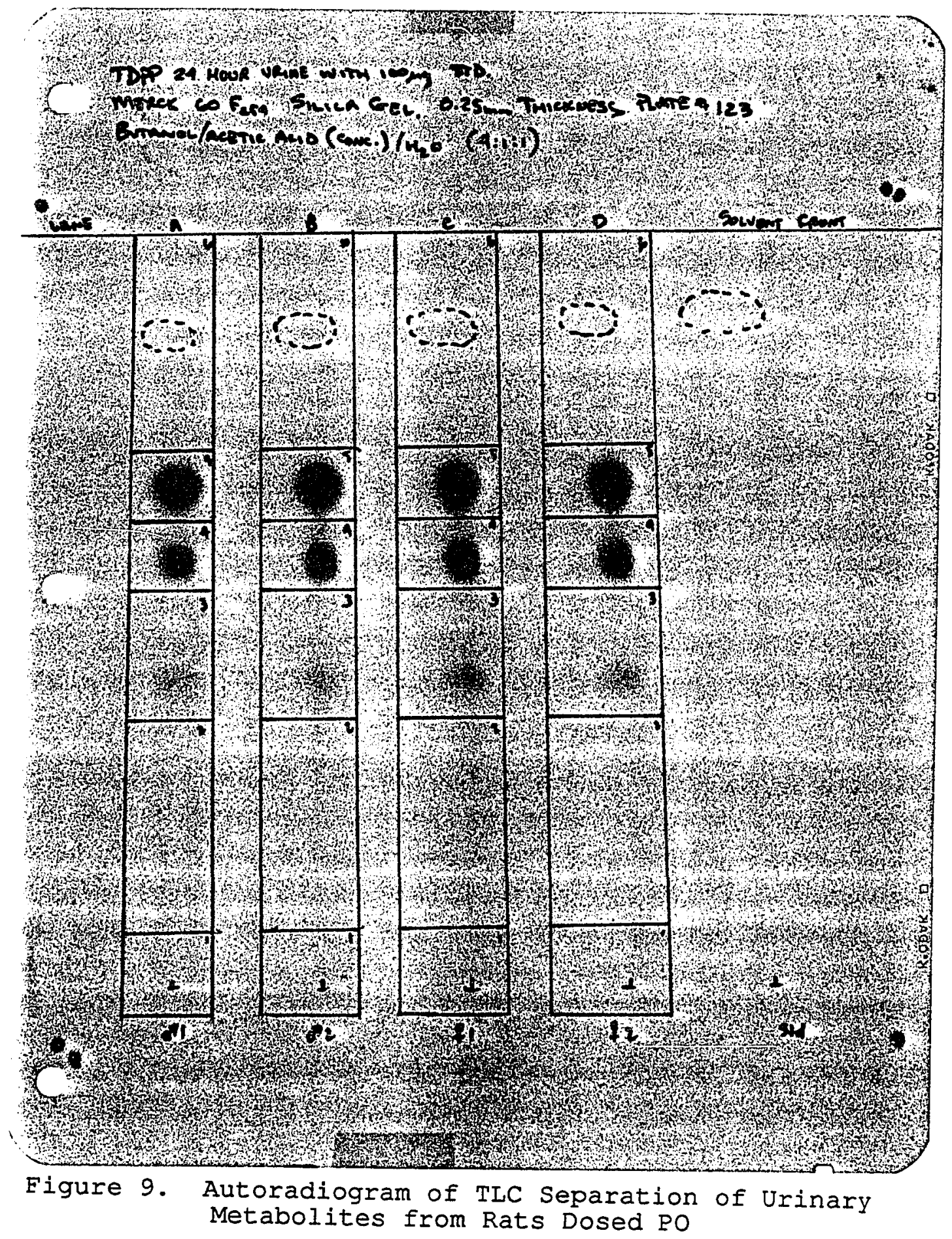




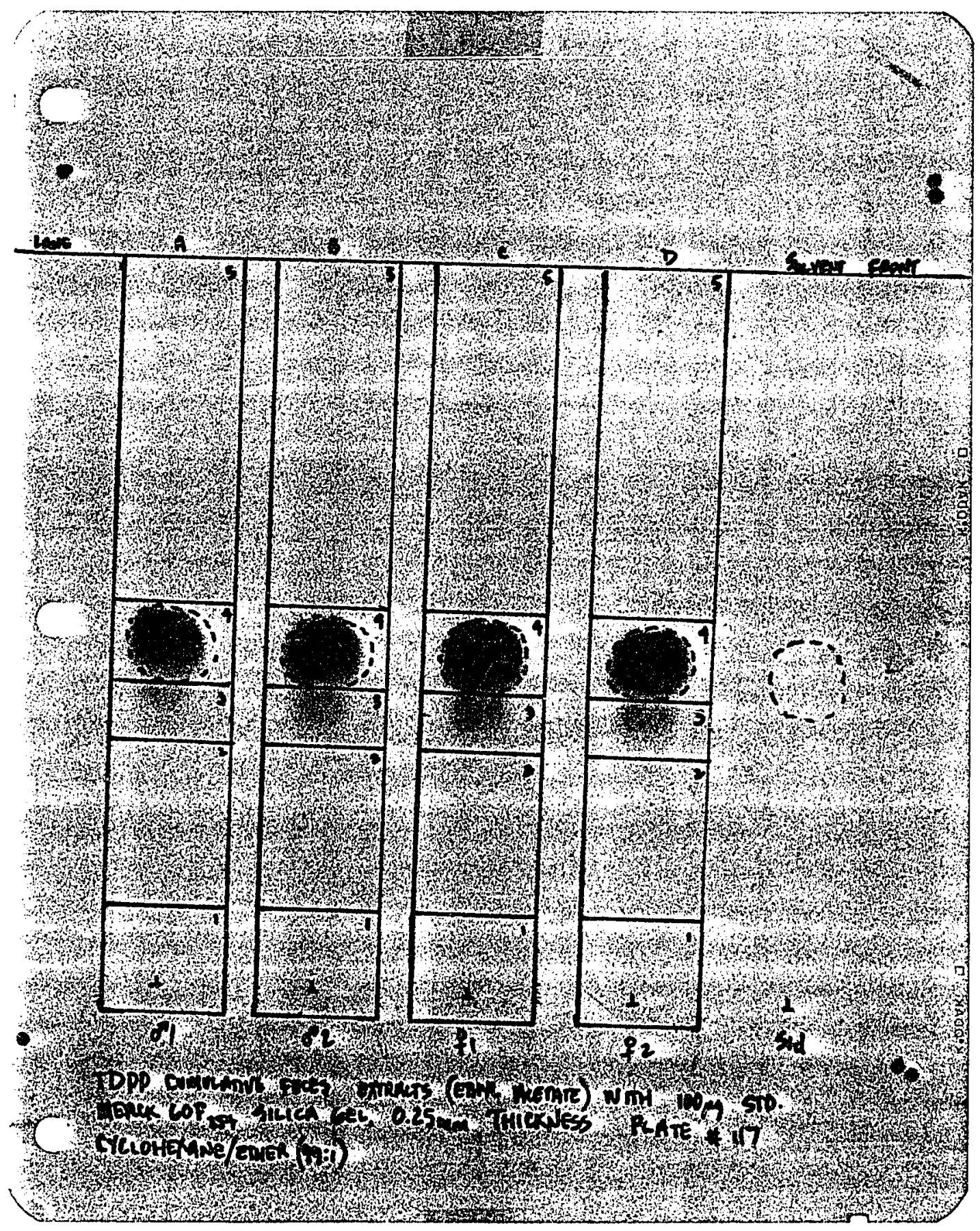

Figure 10. Autoradiogram of TLC Sepiration of Ethyl Acetate Feces Analytes from Rats Dosed PO 
The amount of radiocarbon extractable (using ethyl acetate twice and methanol once) from feces of rats dosed Po ranged from $79 \%$ to $97 \%$ of the approximately $75 \%-80 \%$ dose radiocarbon contained in the feces. Methanol feces extracts from these rats contained between $5 \%$ and $13 \%$ of the dose radiocarbon. From the ethyl acetate extracts of male and female rats $91 \%$ to $94 \%$ of the radiocarbon was characterized by TLC and confirmed by GC/MS to be unchanged TDPP.

Mass spectral data used to confirm the presence of unchanged TDPP in feces extracts purified by preparative TLC from male and female rats dosed $P O$ are shown in Figures 11 and 12 respectively.

The discovery that the majority of the dose material was excreted unchanged in the feces from both male and female dosed rats dosed Po may explain the low mammalian toxicity of this compound, whereby non-absorption is responsible for the compound not reaching the target tissue. The distribution of dose recovered from the rat treated via IP injection further substantiates this finding, due to the fact that the percent distribution of dose recovery was greatly shifted toward urinary excretion. 


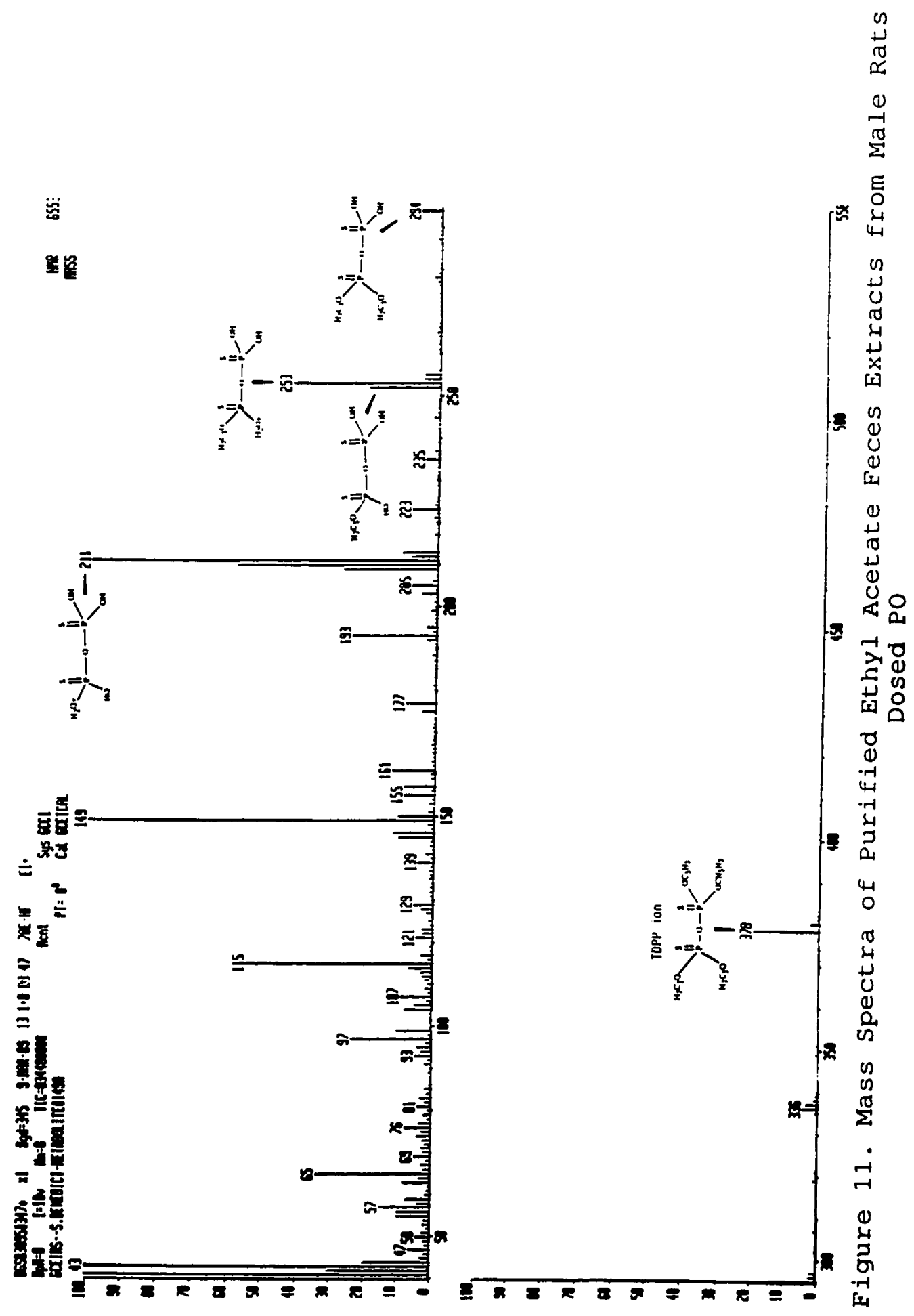




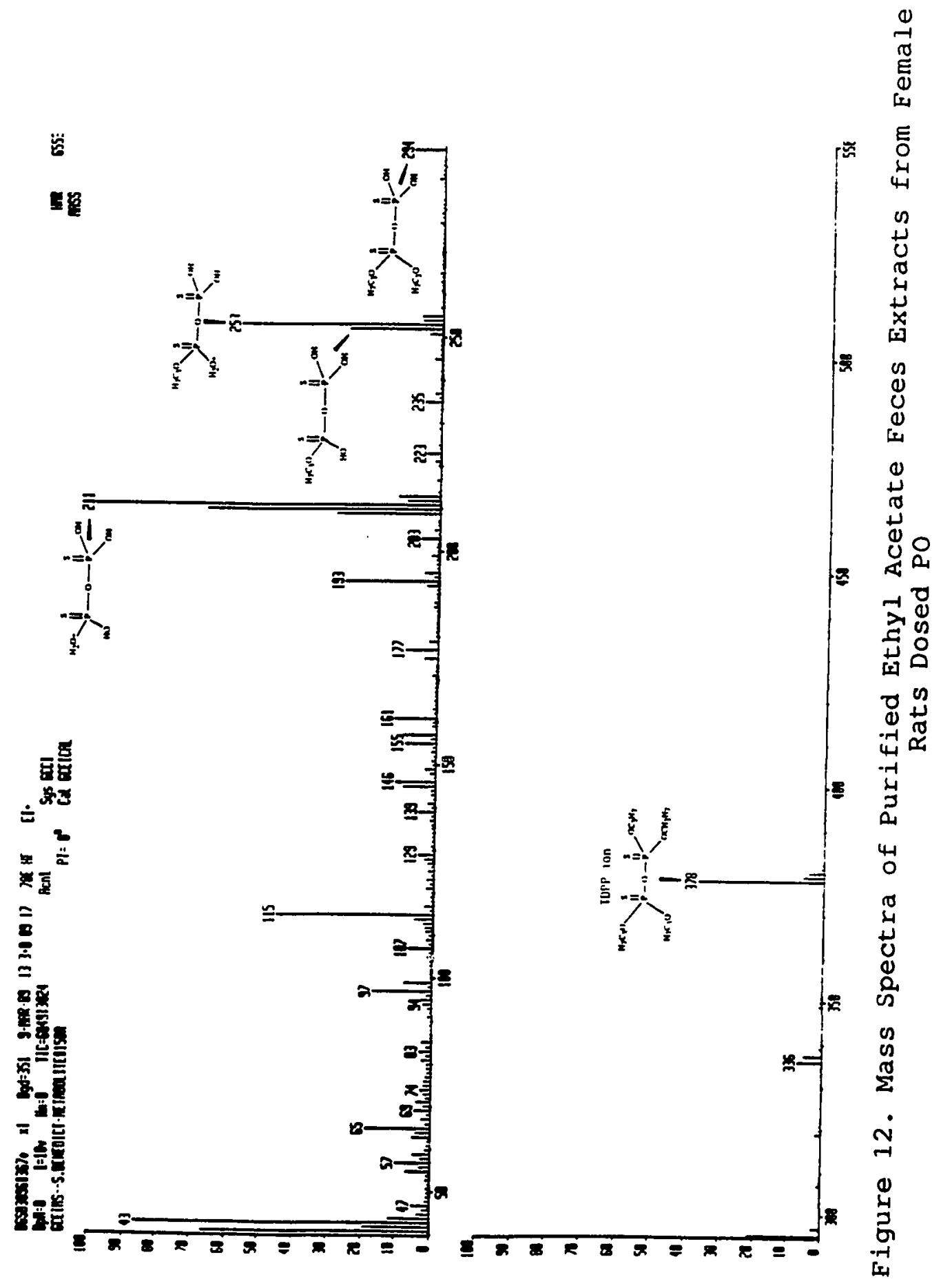


The fact that enterohepatic cycling is not a metabolic pathway for TDPP is substantiated by: the low rate of excretion ( $\sim 5 \%$ per day) from the rat dosed via IP injection as compared to the high rate of excretion seen in rats dosed PO, and by the characterization of fecal metabolites from the IP dosed rat by TLC as polar products rather than unchanged parent compound as seen in rats dosed $P O$.

The non-absorptive nature of TDPP is uncommon among OP insecticides when compared to results obtained in other studies which characterize normal excretion patterns as approximately 708 through the urine and $30 \%$ through the feces (Ford and Menn, 1969; Fisher, 1989).

ivo signs of toxicity were observed in PO dosed rats. Mild signs of toxicity (defecation and depressed appetite) were observed in the IP injection dosed rat which may be evidence of greater toxicity due to more TDPP reaching the target tissue by this route of administration. 
Appendix I. Chemical Information

1) Toxicology

a) Ingestion - $L D_{50}$ in rats, $2710-5010 \mathrm{mg} / \mathrm{kg}$. Single dermal exposures of 1000 and $10,000 \mathrm{mg} / \mathrm{kg}$ produced depression, salivation, lacrimation and diarrhea. Mortality and acute depression were also observed at 2150-10,000 $\mathrm{mg} / \mathrm{kg}$.

b) Dermal - $L_{50}$ in rabbits, greater than 4640 $\mathrm{mg} / \mathrm{kg}$. Single dermal exposure of $4640 \mathrm{mg} / \mathrm{kg}$ produced diarrhea and nasal discharge.

c) Ocular - Non-irritating to rabbit eye. Inhalation - $\mathrm{LC}_{50}$ in rat, greater than $1.1 \mathrm{mg} / \mathrm{L}$
for 1 -hour exposure.

e) TLV - The American Conference of Government Industrial Hygienists has not established a TLV for this compound.

2) Physical and chemical properties

a) Name - 0,0,0,0-Tetrapropyl dithiopyrophosphate

b) Classification - Organophosphate insecticide

c) Physical State - Amber Iiquid

d) Molecular Weight - 378

e) Specific gravity of liquid - 1.121 at $20{ }^{\circ} \mathrm{C}$

f) Water solubility - $30 \mathrm{ppm}$ at $20^{\circ} \mathrm{C}$

g) Vapor pressure - 0.3 microns at $25^{\circ} \mathrm{C}$

h) Boiling point - $170{ }^{\circ} \mathrm{C}$ at $1 \mathrm{~mm} \mathrm{Hg}$

i) Flash Point - $395^{\circ} \mathrm{C}$ 
Appendix II. ${ }^{14} \mathrm{C}$ Dosimetry of Rats Dosed PO

1) Rat weights at time of dosing:
a) male $1=283.4$ grams
b) male $2=294.9$ grams
c) female $1=262.5$ grams
d) female $2=211.7$ grams

2) Dose weights (determined by weight of gavage syringe before and after dose delivery):
a) male $1=0.271$ grams
b) male $2=0.399$ grams
c) female $1=0.307$ grams
d) female $2=0.338$ grams

3) Radiocarbon content of dosing solution (determined by ISC) :
a) $2.33 \times 10^{5} \mathrm{dpm} / \mathrm{mg}$

4) Radiocarbon content of each dose:
a) male 1: (2.33 $\left.10^{5} \mathrm{dpm} / \mathrm{mg}\right)$ (271 $\left.\mathrm{mg}\right)$ $=6.326 \times 10^{7} \mathrm{dpm}$
b) male 2: (2.33 $\left.\times 10^{5} \mathrm{dpm} / \mathrm{mg}\right)$ (399 mg) $=9.314 \times 10^{7} \mathrm{dpm}$
c) female 1:(2.33 × $\left.10^{5} \mathrm{dpm} / \mathrm{mg}\right)$ (307 $\left.\mathrm{mg}\right)$ $=7.167 \times 10^{7} \mathrm{dpm}$
d) female 2: (2.33 x $\left.10^{5} \mathrm{dpm} / \mathrm{mg}\right)$ (338 $\left.\mathrm{mg}\right)$ $=7.691 \times 10^{7} \mathrm{dpm}$

5) Contribution of radiolabeled material to each dose:
a) male 1: (6.326 × $\left.10^{7} \mathrm{dpm}\right) /\left(2.22 \times 10^{9} \mathrm{dpm} / \mathrm{mCi}\right)$ $x(1) /(14.16 \mathrm{mCi} / \mathrm{mmole}) \times(378 \mathrm{mg} / \mathrm{mmole})$
$=0.76 \mathrm{mg}$
b) male 2: $\left(9.314 \times 10^{7} \mathrm{dpm}\right) /\left(2.22 \times 10^{9} \mathrm{dpm} / \mathrm{mCi}\right)$ $\mathrm{x}(1) /(14.16 \mathrm{mCi} / \mathrm{mmole}) \times(378 \mathrm{mg} / \mathrm{mmole})$ $=1.12 \mathrm{mg}$
c) female 1: (7.167 $\left.\times 10^{7} \mathrm{dpm}\right) /\left(2.22 \times 10^{9} \mathrm{dpm} / \mathrm{mCi}\right)$ $x(1) /(14.16 \mathrm{mCi} / \mathrm{mmole}) \times$ (378 $\mathrm{mg} / \mathrm{mmole})$ $=0.86 \mathrm{mg}$



d) female 2: $\left(7.891 \times 10^{7} \mathrm{dpm}\right) /\left(2.22 \times 10^{9} \mathrm{dpm} / \mathrm{mCi}\right)$ $\mathrm{x}(1) /(14.16 \mathrm{mCi} / \mathrm{mmole}) \mathrm{x}$ (378 $\mathrm{mg} / \mathrm{mmole})$ $=0.86 \mathrm{mg}$

6) Contribution of non-radiolabeled material to each dose (dosing solution $=65.618 \mathrm{w} / \mathrm{w} T \operatorname{TDPP})^{1}$ :
a) male 1: (271 $\mathrm{mg}) \times(0.6561)=177.8 \mathrm{mg}$
b) male 2: (399 $\mathrm{mg}) \times(0.6561)=261.8 \mathrm{mg}$
c) female 1: (307 $\mathrm{mg}) \times(0.6561)=201.4 \mathrm{mg}$
d) female 2: (338 $\mathrm{mg}) \times(0.6561)=221.8 \mathrm{mg}$

7) Total weight of compound per dose:
a) male 1: $177.8 \mathrm{mg}+0.76 \mathrm{mg}=178.6 \mathrm{mg}$
b) male 2: $261.8 \mathrm{mg}+1.12 \mathrm{mg}=262.9 \mathrm{mg}$
c) female 1: $201.4 \mathrm{mg}+0.86 \mathrm{mg}=202.3 \mathrm{mg}$
d) female 2: $221.8 \mathrm{mg}=0.86 \mathrm{mg}=222.6 \mathrm{mg}$

8) Dose per rat weight:
a) male 1: $178.6 \mathrm{mg} / 0.2834 \mathrm{~kg}=630.1 \mathrm{mg} / \mathrm{kg}$
b) male 2: $262.9 \mathrm{mg} / 0.2949 \mathrm{~kg}=891.5 \mathrm{mg} / \mathrm{kg}$
c) female 1: $202.3 \mathrm{mg} / 0.2625 \mathrm{~kg}=770.6 \mathrm{mg} / \mathrm{kg}$
d) female 2: 222.6 $\mathrm{mg} / 0.2117 \mathrm{~kg}=1,051.6 \mathrm{mg} / \mathrm{kg}$

12.023 grams non-radiolabeled TDPP (corrected for 97.3\% purity $=1.968$ grams TDPP) was dissolved in 0.977 grams acetone. Percent TDPP $=1.968$ grams / 3.000 grams $=65.61 \%$. This solution delivered the dose to each rat in approximately $700 \mu \mathrm{L}$. 
Appendix III. ${ }^{14} \mathrm{C}$ dosimetry of Rat Dosed by Intraperitoneal Injection

1) Rat weight at time of dosing:

a) 246.0 grams

2) Dose weight (determined by weight of injection syringe before and after dose delivery):

a) 0.129 grams

3) Radiocarbon content of dosing solution (determined by LSC):

a) $5.975 \times 10^{5} \mathrm{dpm} / \mathrm{mg}$

4) Radiocarbon content of each dose:

a) $\left(5.975 \times 10^{5} \mathrm{dpm} / \mathrm{mg}\right)(129 \mathrm{mg})$ $=7.7074 \times 10^{7} \mathrm{dpm}$

5) Contribution of radiolabeled material to each dose:

a) $\left(7.7074 \times 10^{7} \mathrm{dpm}\right) /\left(2.22 \times 10^{9} \mathrm{dpm} / \mathrm{mCi}\right)$ $\mathrm{x}(1) /(14.16 \mathrm{mCi} / \mathrm{mmole}) \times(378 \mathrm{mg} / \mathrm{mmole})$ $=0.93 \mathrm{mg}$

6) Contribution of non-radiolabeled material to each dose (dosing solution $=92.10 \% \mathrm{w} / \mathrm{w} T \mathrm{TDPP}^{1}$ :

a) $(129 \mathrm{mg}) \times(0.9210)=118.0 \mathrm{mg}$

7) Total weight of compound per dose:

a) $118.0 \mathrm{mg}+0.93 \mathrm{mg}=118.9 \mathrm{mg}$

8) Dose per rat weight:

a) $118.9 \mathrm{mg} / 0.246 \mathrm{~kg}=483.7 \mathrm{mg} / \mathrm{kg}$

1 A more concentrated dosing solution was required thus non-radiolabeled neat material was used in preparation of the dosing solution. This solution delivered the dose in approximately $115 \mu \mathrm{L}$. 
Baillie, R.G., and Wright D. 1985, Comprehensive Insect Physiology Biochemistry and Pharmacology, 11, Pergamon Press, New York, p 424 .

Carson, R. 1962, Silent Spring, Houghton Mifflin, New York, Chapter 9.

Casarett, L.J. and Doull, J. 1986, Toxicology, MCMillan, New York, p 365 .

Casida, J.E. 1973, Insecticide biochemistry, Annual Rev. of Biochem., 42, p 259-278.

Ellin, R.I. 1982, Anomalies in theories and therapy of intoxication by potent organophosphorus anticholinesterase compounds, Gen Pharmacol., 13, pp 457-466.

Eto, M. 1974, Organophosphorus Pesticides: Organic and Biological Chemistry, CRC Press, New York, pp 128-136.

Fisher, G.D. 1989, Technical report, N-(mercaptomethyl) phthalimide-s- 10,0 -dimethyl phosphorodithioate metabolism in the rat, Ciba-Geigy Corporation, Connecticut.

Ford, I.M. and Menn, J.J. 1979, Technical Report No. ARCB-9, Metabolism of 0-Ethyl-S-phenyl ethylposphono dithioate: Balance Study in the Rat, Stauffer Chemical Co, California.

Gerolt, P. 1976, The mode of action of insecticides: accelerated water loss and reduced respiration in insecticide-treated Musca domestica L., Pestic. Sci., 7, pp 604-620.

Goodman, L.S. and Gilman, A.G. 1985, The Phamacological Basis of Therapeutics, McMillan, New York, p 79.

Gray, A.P. 1984, Design and structure-activity relationships of antidotes to organophosphorus anticholinesterase agents, Drug Metabolism Reviews, 15, pp 560.

Holmstedt, B. 1971, Distribution and determination of cholinesterases in mammals, Bull. W.H.O., 44,p 99. 
Johnson, M.K. 1975, The delayed neuropathy caused by some organophosphorus esters: mechanism and challenge. CRC Crit. Rev. Toxicol., 3, pp 289-316.

Katz, B., and Miledi, R. 1965, The measurement of synaptic delay, and the time course of acetylcholine release at the neuromuscular junction. Proc. R. Sci. Lond., 161, pp 483-495.

Kerkut, G.A. and Gilbert, L.I. 1985, Comprehensive Insect Physiology Biochemistry and Pharmacology, 11, Pergamon, New York, p 416

Massoulie, J., and Bon, S. 1982, The molecular forms of cholinesterase and acetylcholinesterase in vertebrates. Annul. Rev. Neurosci., 5, p 106.

Meeter, E., Wolyhuis, O.I. and Van Benthem, R.M.J. 1971, The anticholinesterase hypothermia in the rat: It's practical application in the study of the central effectiveness of oximes, Bull. W.H.O., 44, p 251.

Metcalf, C.I., Flint, W.P. and Metcalf, R.L. 1951, Destructive and Useful Insects, McGraw-Hill, pp 255-259.

O'Brien, R.D. 1960, Toxic Phosphorus Esters: Chemistry, Metabolism and Biologicl Effects, Acedemic, New York, p 87 .

Rossier, J. 1977, Choline acetyltransferase: a review with special reference to its cellular and subcellular localization. Int. Rev. Neurobiol., 20, p 283-337. Sine, C. 1987, Farm Chemicals Handbook, Meister, Willoughby,
OH, p C21.

Stauffer Chemical Co. 1985, Product safety bulletin, Westport, CT. p 3 .

Wiaderkiewicz, R., Walter, z. and Reimschussel, W. 1986, Sites of methylation of DNA bases by the action of organophosphorus insecticides in vitro, Acta Biochim. Pol., 33, pp 73-85. 